Supporting information for

\title{
Formation of protonated ortho-quinonimide from ortho-iodoaniline in gas phase by a molecular-oxygen-mediated, ortho-isomer-specific fragmentation mechanism
}

\author{
Ramu Errabelli, Zhaoyu Zheng, and Athula B. Attygalle* \\ Center for Mass Spectrometry, Department of Chemistry, and Chemical Biology, Stevens \\ Institute of Technology, Hoboken, New Jersey 07030
}

Table of Contents

\begin{tabular}{|c|c|c|}
\hline Figure S1 & $\begin{array}{l}\text { Combined product-ion spectra recorded from mass-selected } m / z 221 \\
\left.(\mathrm{M}+\mathrm{H})^{+} \text {ion from } p \text {-iodo[ }{ }^{15} \mathrm{~N}\right] \text { aniline }(\mathbf{A}), m / z 223(\mathrm{M}+\mathrm{D})^{+} \text {ion from } p \text { - } \\
\text { iodo }\left[\mathrm{N}^{2} \mathrm{H}_{2}\right] \text { aniline }(\mathbf{B}) \text {, and } m / z 220(\mathrm{M}+\mathrm{H})^{+} \text {from } p \text {-iodoaniline }(\mathbf{C}) \text {. } \\
\text { Ions were generated by electrospraying a 100-ppm solution of } p \text { - } \\
\text { iodo }\left[{ }^{15} \mathrm{~N}\right] \text { aniline or } p \text {-iodoaniline dissolved in acetonitrile:water }(50: 50) \text {. } \\
\left.\text { In contrast, the } p \text {-iodo[ } \mathrm{N}^{2} \mathrm{H}_{2}\right] \text { aniline solution was prepared in } \\
\text { acetonitrile: } \mathrm{D}_{2} \mathrm{O}(50: 50) \text {. Mass-selected ions were subjected to } \\
\text { fragmentation at a trap-collision energy setting of } 28 \mathrm{eV} \text {, and separation } \\
\text { by ion mobility before they were transferred to the ToF analyzer via the } \\
\text { transfer collision cell held at } 2 \mathrm{eV} \text {. Insets display arrival-time profiles of } \\
\text { ion-mobility separated ions. The three spectra }(\mathbf{a}, \mathbf{b} \text {, and } \mathbf{c}) \text { represent all } \\
\text { spectra coadded and averaged for the whole } 0-10 \mathrm{~ms} \text { period. Other } \\
\text { instrumental parameters were as follows: sampling-cone voltage } 30 \mathrm{~V} \text {, } \\
\text { capillary voltage } 2.85 \mathrm{kV} \text {, source and desolvation temperatures } 80{ }^{\circ} \mathrm{C} \\
\text { and } 100{ }^{\circ} \mathrm{C} \text {, respectively, cone and desolvation gas flows } 38 \mathrm{~L} / \mathrm{h} \text {, and } 138 \\
\mathrm{~L} / \mathrm{h} \text {. IM separation was carried out a wave velocity of } 1500 \mathrm{~m} / \mathrm{s} \text {, a wave } \\
\text { height } 40.0 \mathrm{~V} \text { and IMS gas }\left(\mathrm{N}_{2}\right) \text { flow was } 140 \mathrm{~mL} / \mathrm{min} \text {. }\end{array}$ & $\overline{\mathrm{S} 5}$ \\
\hline Figure S2 & $\begin{array}{l}\text { Trap-fragmentation product-ion spectra recorded under non- } \\
\text { mobility conditions (i.e. no helium or nitrogen in the mobility cell) } \\
\text { from mass-selected } m / z 220 \text { ions generated under ESI conditions } \\
\text { from protonated ortho- (a), meta- (b) and para-iodoaniline (c). } \\
\text { Samples were infused as } 100 \text {-ppm solutions in acetonitrile:water } \\
(50: 50) \text { and data were acquired for } 0.5 \mathrm{~min} \text {. The spectra displayed } \\
\text { were generated by coadding and averaging data for the whole } \\
\text { acquisition period. The sampling cone voltage was } 30 \mathrm{~V} \text {, capillary }\end{array}$ & S6 \\
\hline
\end{tabular}

${ }^{*}$ Correspondence to: Dr. Athula Attygalle, Center for Mass Spectrometry, Department of Chemistry, and Chemical Biology, Stevens Institute of Technology, Hoboken, New Jersey 07030, USA.

E-mail: athula.attygalle@stevens.edu 


\begin{tabular}{|c|c|c|}
\hline & $\begin{array}{l}\text { voltage was } 2.85 \mathrm{kV} \text {, source and desolvation heater temperatures } \\
\text { were } 80{ }^{\circ} \mathrm{C} \text { and } 100{ }^{\circ} \mathrm{C} \text {, cone- and desolvation-gas flows were } 38 \\
\mathrm{~L} / \mathrm{h} \text {, and } 138 \mathrm{~L} / \mathrm{h} \text {, respectively. Trap and Transfer collision } \\
\text { energies were } 15 \text { and } 2 \mathrm{eV} \text {, respectively. }\end{array}$ & \\
\hline Figure S3 & $\begin{array}{l}\text { Trap fragmentation followed by ion-mobility separation spectra of } \\
\text { iodoanilines, } \mathrm{m} / z 223(\mathrm{M}+\mathrm{D})^{+} \text {ion }(\mathrm{H} / \mathrm{D} \text { exchange) generated under } \\
\text { ESI method by infusing a } 100 \mathrm{ppm} \text { solution of iodoanilines } \\
\text { respectively, in acetonitrile: } \mathrm{D}_{2} \mathrm{O}(50: 50) \text { solvent. The three spectra } \\
(\mathbf{A}, \mathbf{B} \text {, and } \mathbf{C}) \text { represent all spectra coadded and averaged for the } \\
\text { whole } 0-10 \mathrm{~ms} \text { period of the mobilogram. The sampling cone } \\
\text { voltage was } 30 \mathrm{~V} \text {, capillary voltage was } 2.85 \mathrm{kV} \text {, source and } \\
\text { desolvation temperature was } 80{ }^{\circ} \mathrm{C} \text { and } 100{ }^{\circ} \mathrm{C} \text {, cone gas and } \\
\text { desolvation gas flow was } 38 \mathrm{~L} / \mathrm{h} \text {, and } 138 \mathrm{~L} / \mathrm{h} \text { and trap collision } \\
\text { energy was } 28 \mathrm{eV} \text { and transfer collision energy was } 2 \mathrm{eV} \text {. IM } \\
\text { separation was carried out a wave velocity of } 1500 \mathrm{~m} / \mathrm{s} \text {, a wave } \\
\text { height } 40.0 \mathrm{~V} \text { and IMS gas }\left(\mathrm{N}_{2}\right) \text { flow was } 140 \mathrm{~mL} / \mathrm{min} \text {. }\end{array}$ & S7 \\
\hline Figure S4 & $\begin{array}{l}\text { Combined relative electronic and zero point energies [in } \mathrm{kJ} / \mathrm{mol} \\
\text { computed for } 0 \mathrm{~K} \text { by the density functional theory method B3LYP using } \\
\text { a } 6-311++\mathrm{G}(2 \mathrm{~d}, 2 \mathrm{p}) \text { basis set] and molecular structures of energy- } \\
\text { optimized ions associated with the formation of } \mathrm{m} / \mathrm{z} 125 \text { and } 109 \text { ions } \\
\text { resulting from the } \mathrm{O}_{2} \text { addition to meta-dehydroanilinium-radical anion } \\
\text { (4). }\end{array}$ & S8 \\
\hline Figure S5 & $\begin{array}{l}\text { Combined relative electronic and zero point energies [in } \mathrm{kJ} / \mathrm{mol} \\
\text { computed for } 0 \mathrm{~K} \text { by the density functional theory method B3LYP using } \\
\text { a } 6-311++\mathrm{G}(2 \mathrm{~d}, 2 \mathrm{p}) \text { basis set] and molecular structures of energy- } \\
\text { optimized ions associated with the formation of } \mathrm{m} / \mathrm{z} 125 \text { and } 109 \text { ions } \\
\text { resulting from the } \mathrm{O}_{2} \text { addition to para-dehydroanilinium-radical anion } \\
\text { (2). }\end{array}$ & S9 \\
\hline Figure S6 & $\begin{array}{l}\text { Arrival time distributions (ATDs) recorded from the in-source generated } \\
m / z 93 \text { ion from } o \text { - (a), } m \text { - (b), or } p \text {-iodoaniline }(\mathbf{c}) \text {, which were mass } \\
\text { selected and subjected to ion mobility separation. Ions were generated } \\
\text { under ESI conditions (capillary voltage } 2.85 \mathrm{kV} \text { and cone voltage of } 65 \\
\mathrm{~V} \text { ) by infusing a } 100 \text {-ppm solution of each iodoanilines in } 50: 50 \\
\text { acetonitrile:water. The source and desolvation temperatures were } 80{ }^{\circ} \mathrm{C} \\
\text { and } 100{ }^{\circ} \mathrm{C} \text {, respectively. The cone gas and deslovation gas flows were } \\
38 \mathrm{~L} / \mathrm{h} \text {, and } 138 \mathrm{~L} / \mathrm{h} \text {, respectively. The trap collision energy was } 4 \mathrm{eV} \\
\text { and transfer collision energy was } 2 \mathrm{eV} \text {. IM separation was carried out a } \\
\text { wave velocity of } 1500 \mathrm{~m} / \mathrm{s} \text {, wave height } 40.0 \mathrm{~V} \text { using nitrogen as IMS } \\
\text { gas at a flow of } 140 \mathrm{~mL} / \mathrm{min} \text {. Insets show spectra that represent ions }\end{array}$ & $\mathrm{S} 10$ \\
\hline
\end{tabular}




\begin{tabular}{|c|c|c|}
\hline & delivered to the ToF analyzer at specific arrival times. & \\
\hline Figure S7 & $\begin{array}{l}\text { Arrival-time distributions (ATDs) recorded from the mass-selected } \\
m / z 93 \text { ion of } p \text {-iodoaniline (A), and that of } m \text {-iodoaniline (B) } \\
\text { recorded at a Transfer-collision energy setting of } \mathbf{2 0} \mathbf{e V} \text {. Insets } \\
\text { show average spectra that represent ions delivered to the ToF } \\
\text { analyzer at specific arrival times. Ions were generated by } \\
\text { electrospraying } 100 \text {-ppm solutions in } 50: 50 \text { acetonitrile:water at a } \\
\text { flow rate of } 20 \mu \mathrm{L} / \text { min. Other experimental conditions were as } \\
\text { follows: sampling-cone voltage } 65 \mathrm{~V} \text {; capillary voltage } 2.85 \mathrm{kV} \text {; } \\
\text { source and desolvation heater temperatures of } 80 \text { and } 100^{\circ} \mathrm{C} \text {, } \\
\text { respectively; cone and desolvation gas flow rates were } 38 \text { and } 138 \\
\mathrm{~L} / \mathrm{h} \text {, respectively; Trap-collision energy } 4.0 \mathrm{eV} \text {. IM separations } \\
\text { were carried out at a wave velocity of } 1500 \mathrm{~m} / \mathrm{s} \text {, a wave height } \\
40.0 \mathrm{~V} \text {, and mobility gas }\left(\mathrm{N}_{2} \text { ) flow rate } 140 \mathrm{~mL} / \mathrm{min} \text {. }\right.\end{array}$ & S11 \\
\hline Figure S8 & $\begin{array}{l}\text { Chronogram recorded by monitoring the intensisties of } m / z 93 \text { (a), and } \\
125 \text { (b) ions on two detection channels. A 100-ppm solution of aniline } \\
\text { was nebulized under ESI conditions by infusing via the main spray probe } \\
\text { continuously. At } 2.0 \mathrm{~min} \text {, a } 10-\mu \mathrm{L} \text { aliquot of a } p \text {-iodoaniline solution } \\
(100 \mathrm{ppm} \text { in } 50: 50 \text { acetonitrile:water) was introduced via the lock-spray } \\
\text { probe. Other instrumental parameters were: The sampling cone voltage } \\
70 \mathrm{~V} \text {; capillary voltage } 3.85 \mathrm{kV} \text {; source and desolvation temperature } 80 \\
{ }^{\circ} \mathrm{C} \text { and } 100{ }^{\circ} \mathrm{C} \text {, respectively; cone and deslovation gas flow } 34 \mathrm{~L} / \mathrm{h} \text {, and } \\
138 \mathrm{~L} / \mathrm{h} \text {, respectively; trap and transfer collision energy } 4 \text { and } 2 \mathrm{eV} \text {, } \\
\text { respectively; IM wave velocity of } 1500 \mathrm{~m} / \mathrm{s} \text {; IM wave height } 40.0 \mathrm{~V} \text {; } \\
\text { IMS }\left(\mathrm{N}_{2}\right) \text { gas flow } 140 \mathrm{~mL} / \mathrm{min} \text {. }\end{array}$ & S12 \\
\hline Table S1 & $\begin{array}{l}\text { Accurate mass data of some ions generated from the interaction of } \\
\text { molecular oxygen with dehydroanilinium ions. }\end{array}$ & S13 \\
\hline Table S2 & $\begin{array}{l}\text { Atom coordinates and absolute energies of energy-optimized O2 } \\
\text { molecule. }\end{array}$ & S14 \\
\hline Table S3 & Absolute energies of energy-optimized $\mathrm{O}$ atom. & S15 \\
\hline Table S4 & $\begin{array}{l}\text { Atom coordinates and absolute energies of energy-optimized } \\
\text { ortho-dehydroanilinium radical-cations }(\mathrm{m} / \mathrm{z} 93 \text { ion })\end{array}$ & S16 \\
\hline Table S5. & $\begin{array}{l}\text { Atom coordinates and absolute energies of energy-optimized } o- \\
\text { peroxylbenzenaminium radical-cation }(\mathrm{m} / \mathrm{z} 125)\end{array}$ & S17 \\
\hline Table S6. & Atom coordinates and absolute energies of the transition state of & S18 \\
\hline
\end{tabular}




\begin{tabular}{|c|c|c|}
\hline & OH radical loss from $o$-peroxylbenzenaminium radical-cation. & \\
\hline Table S7. & $\begin{array}{l}\text { Atom coordinates and absolute energies of the complex of } \mathrm{OH} \\
\text { radical and protonated ortho-quinonimide. }\end{array}$ & S19 \\
\hline Table S8. & $\begin{array}{l}\text { Atom coordinates and absolute energies of protonated ortho- } \\
\text { quinonimide }(\mathrm{m} / \mathrm{z} 108) \text {. }\end{array}$ & S20 \\
\hline Table S9. & $\begin{array}{l}\text { Atom coordinates and absolute energies of protonated cyclopenta- } \\
\text { 2,4-dien-1-imine }(\mathrm{m} / \mathrm{z} 80) \text {. }\end{array}$ & S21 \\
\hline Table S10. & $\begin{array}{l}\text { Atom coordinates and absolute energies of energy-optimized meta- } \\
\text { dehydroanilinium radical-cations }(\mathrm{m} / \mathrm{z} 93 \text { ion) }\end{array}$ & S22 \\
\hline Table S11. & $\begin{array}{l}\text { Atom coordinates and absolute energies of energy-optimized } m \text { - } \\
\text { peroxylbenzenaminium radical-cation }(\mathrm{m} / \mathrm{z} 125)\end{array}$ & S23 \\
\hline Table S12. & $\begin{array}{l}\text { Atom coordinates and absolute energies of protonated meta- } \\
\text { quinonimide }(\mathrm{m} / \mathrm{z} 109) \text {. }\end{array}$ & S24 \\
\hline Table S13. & $\begin{array}{l}\text { Atom coordinates and absolute energies of energy-optimized } p \text { - } \\
\text { dehydroanilinium radical-cations }(\mathrm{m} / \mathrm{z} 93 \text { ion })\end{array}$ & S25 \\
\hline Table S14. & $\begin{array}{l}\text { Atom coordinates and absolute energies of energy-optimized } p \text { - } \\
\text { peroxylbenzenaminium radical-cation }(m / z 125)\end{array}$ & S26 \\
\hline Table S15. & $\begin{array}{l}\text { Atom coordinates and absolute energies of protonated para- } \\
\text { quinonimide }(m / z 109) \text {. }\end{array}$ & S27 \\
\hline
\end{tabular}




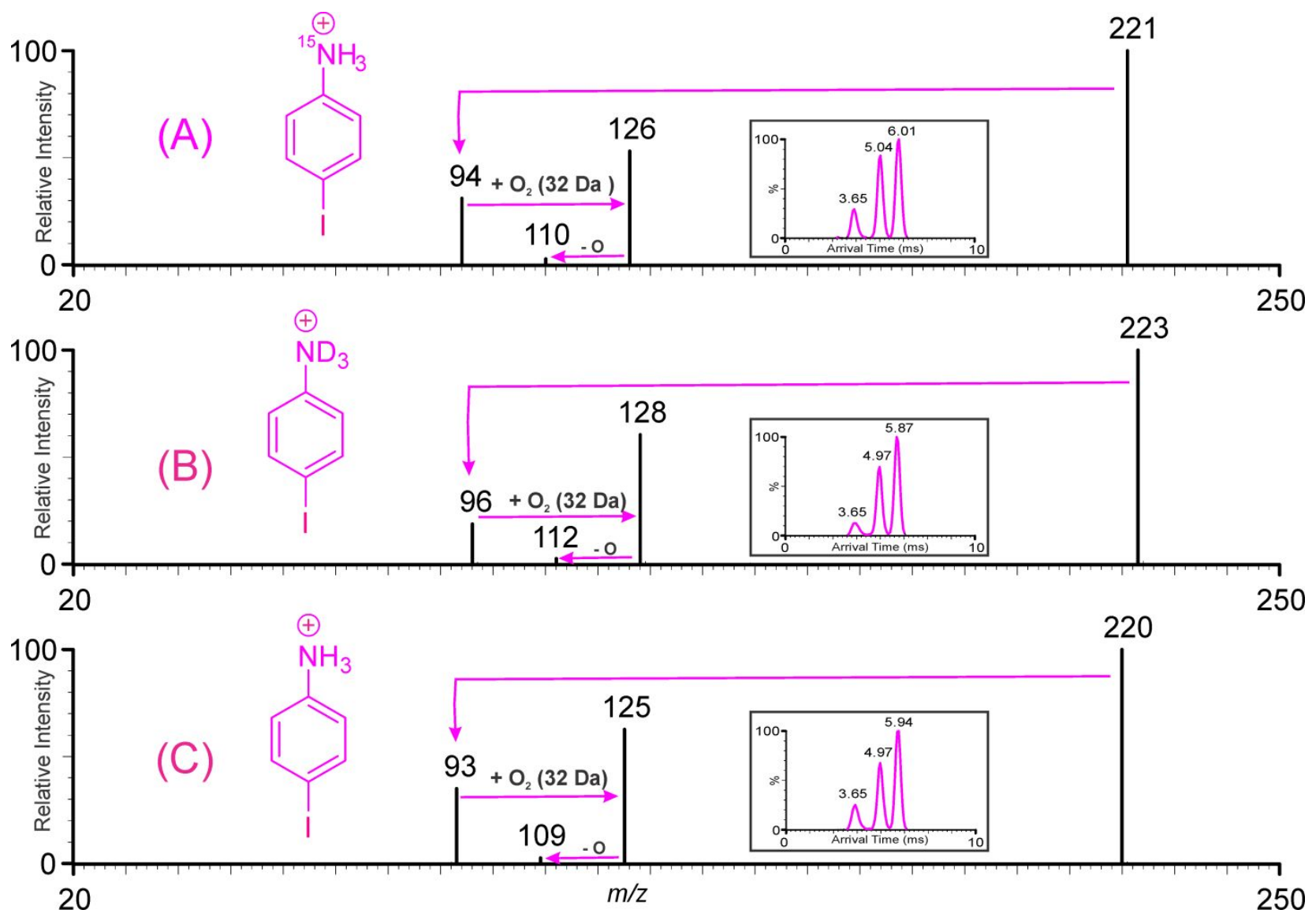

Figure S1. Combined product-ion spectra recorded from mass-selected $m / z 221(\mathrm{M}+\mathrm{H})^{+}$ion from $p$ iodo $\left[{ }^{15} \mathrm{~N}\right]$ aniline (A), $m / z 223(\mathrm{M}+\mathrm{D})^{+}$ion from $p$-iodo $\left[\mathrm{N}^{2} \mathrm{H}_{2}\right]$ aniline $(\mathbf{B})$, and $m / z 220(\mathrm{M}+\mathrm{H})^{+}$ from $p$-iodoaniline $(\mathbf{C})$. Ions were generated by electrospraying a 100 -ppm solution of $p$ iodo $\left[{ }^{15} \mathrm{~N}\right]$ aniline or $p$-iodoaniline dissolved in acetonitrile:water (50:50). In contrast, the $p$ iodo $\left[\mathrm{N}^{2} \mathrm{H}_{2}\right]$ aniline solution was prepared in acetonitrile: $\mathrm{D}_{2} \mathrm{O}$ (50:50). Mass-selected ions were subjected to fragmentation at a trap-collision energy setting of $28 \mathrm{eV}$, and separation by ion mobility before they were transferred to the ToF analyzer via the transfer collision cell held at $2 \mathrm{eV}$. Insets display arrival-time profiles of ion-mobility separated ions. The three spectra (a, $\mathbf{b}$, and c) represent all spectra coadded and averaged for the whole $0-10 \mathrm{~ms}$ period. Other instrumental parameters were as follows: sampling-cone voltage $30 \mathrm{~V}$, capillary voltage 2.85 $\mathrm{kV}$, source and desolvation temperatures $80{ }^{\circ} \mathrm{C}$ and $100^{\circ} \mathrm{C}$, respectively, cone and desolvation gas flows $38 \mathrm{~L} / \mathrm{h}$, and $138 \mathrm{~L} / \mathrm{h}$. IM separation was carried out a wave velocity of $1500 \mathrm{~m} / \mathrm{s}$, a wave height $40.0 \mathrm{~V}$ and IMS gas $\left(\mathrm{N}_{2}\right)$ flow was $140 \mathrm{~mL} / \mathrm{min}$. 


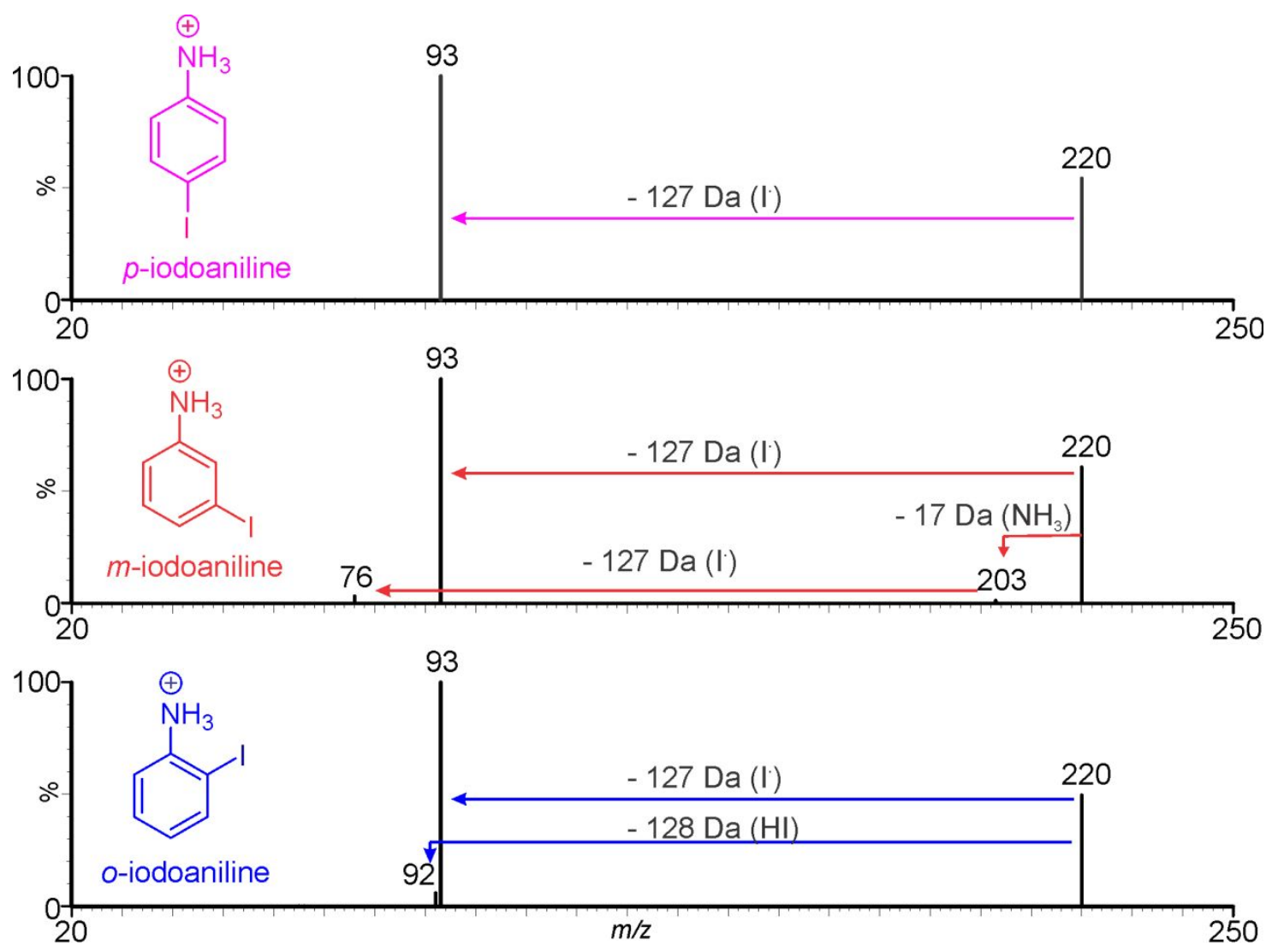

Figure S2. Trap-fragmentation product-ion spectra recorded under non-mobility conditions (i.e. no helium or nitrogen in the mobility cell) from mass-selected $\mathrm{m} / \mathrm{z} 220$ ions generated under ESI conditions from protonated ortho- (a), meta- (b) and para-iodoaniline (c). Samples were infused as 100-ppm solutions in acetonitrile:water (50:50) and data were acquired for $0.5 \mathrm{~min}$. The spectra displayed were generated by coadding and averaging data for the whole acquisition period. The sampling cone voltage was $30 \mathrm{~V}$, capillary voltage was $2.85 \mathrm{kV}$, source and desolvation heater temperatures were $80{ }^{\circ} \mathrm{C}$ and 100 ${ }^{\circ} \mathrm{C}$, cone- and desolvation-gas flows were $38 \mathrm{~L} / \mathrm{h}$, and $138 \mathrm{~L} / \mathrm{h}$, respectively. Trap and Transfer collision energies were 15 and $2 \mathrm{eV}$, respectively. 


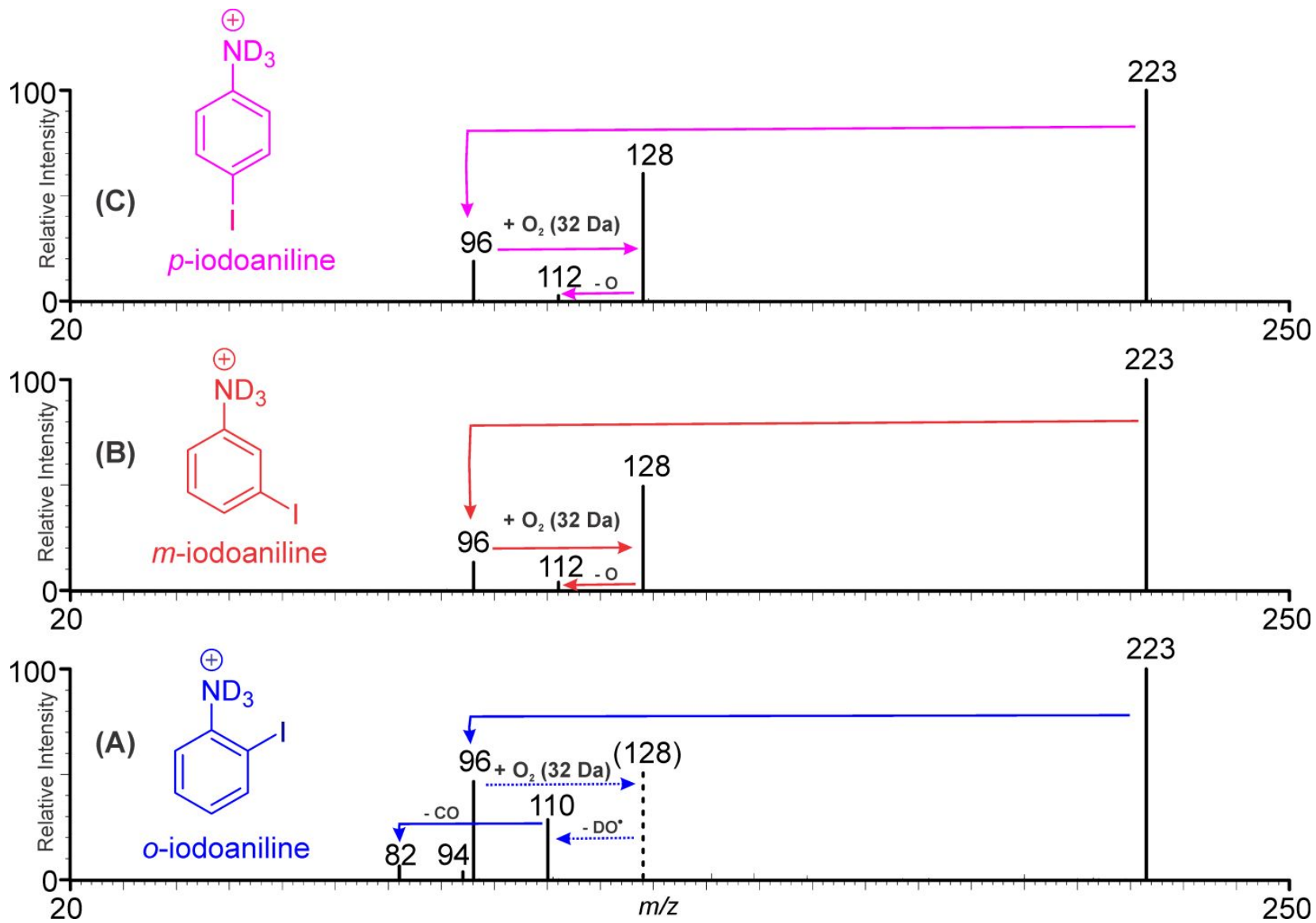

Figure S3: Trap fragmentation followed by ion-mobility separation spectra of iodoanilines, $\mathrm{m} / \mathrm{z} 223$ $(\mathrm{M}+\mathrm{D})^{+}$ion $(\mathrm{H} / \mathrm{D}$ exchange) generated under ESI method by infusing a $100 \mathrm{ppm}$ solution of iodoanilines respectively, in acetonitrile: $\mathrm{D}_{2} \mathrm{O}$ (50:50) solvent. The three spectra (A, B, and $\left.\mathbf{C}\right)$ represent all spectra coadded and averaged for the whole $0-10 \mathrm{~ms}$ period of the mobilogram. The sampling cone voltage was $30 \mathrm{~V}$, capillary voltage was $2.85 \mathrm{kV}$, source and desolvation temperature was $80^{\circ} \mathrm{C}$ and $100{ }^{\circ} \mathrm{C}$, cone gas and desolvation gas flow was $38 \mathrm{~L} / \mathrm{h}$, and $138 \mathrm{~L} / \mathrm{h}$ and trap collision energy was $28 \mathrm{eV}$ and transfer collision energy was $2 \mathrm{eV}$. IM separation was carried out a wave velocity of $1500 \mathrm{~m} / \mathrm{s}$, a wave height $40.0 \mathrm{~V}$ and IMS gas $\left(\mathrm{N}_{2}\right)$ flow was 140 $\mathrm{mL} / \mathrm{min}$. 


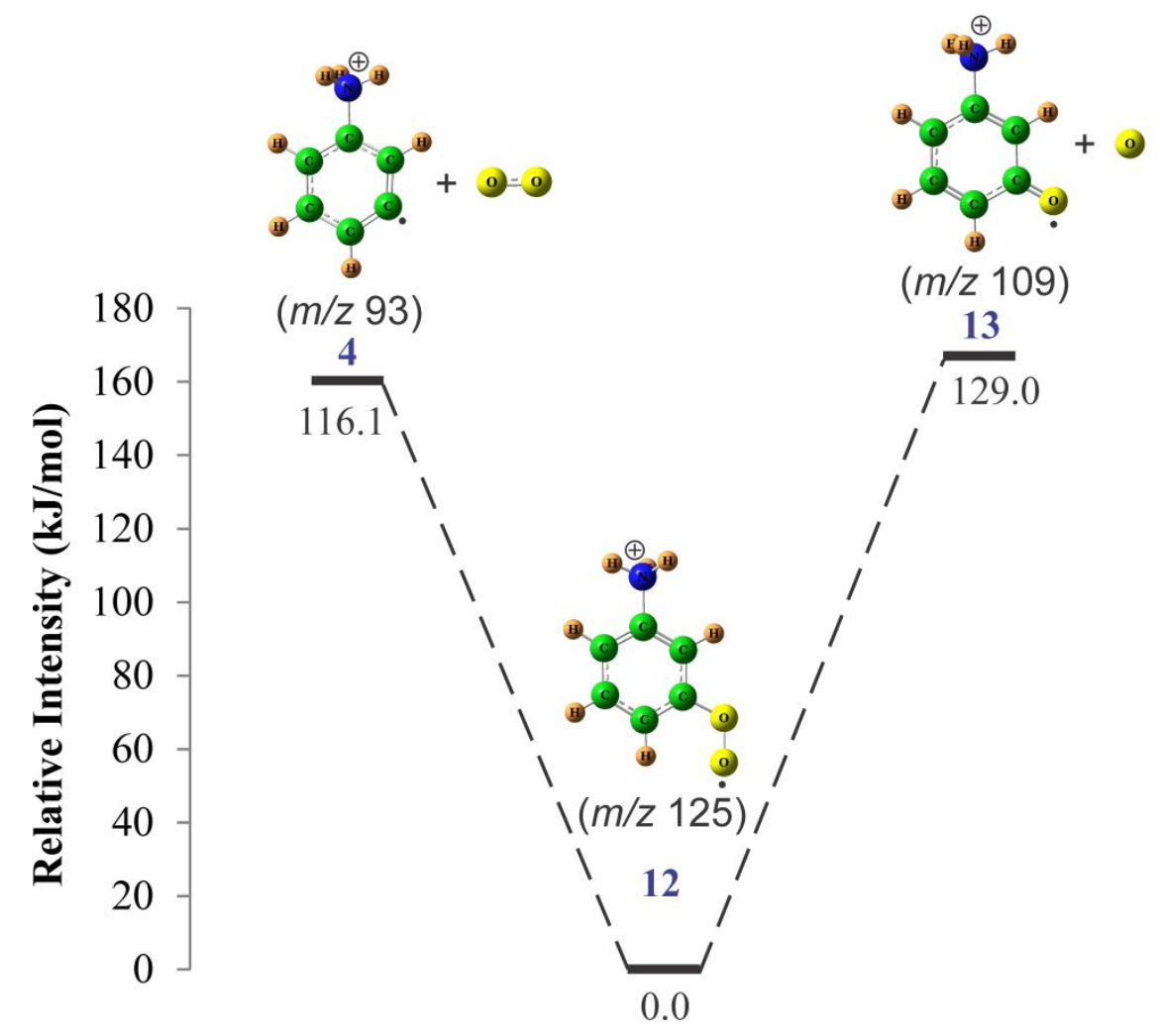

Figure S4. Combined relative electronic and zero point energies [in $\mathrm{kJ} / \mathrm{mol}$ computed for $0 \mathrm{~K}$ by the density functional theory method B3LYP using a 6-311+ $+\mathrm{G}(2 \mathrm{~d}, 2 \mathrm{p})$ basis set] and molecular structures of energy-optimized ions associated with the formation of $m / z 125$ and 109 ions resulting from the $\mathrm{O}_{2}$ addition to meta-dehydroanilinium-radical anion (4). 


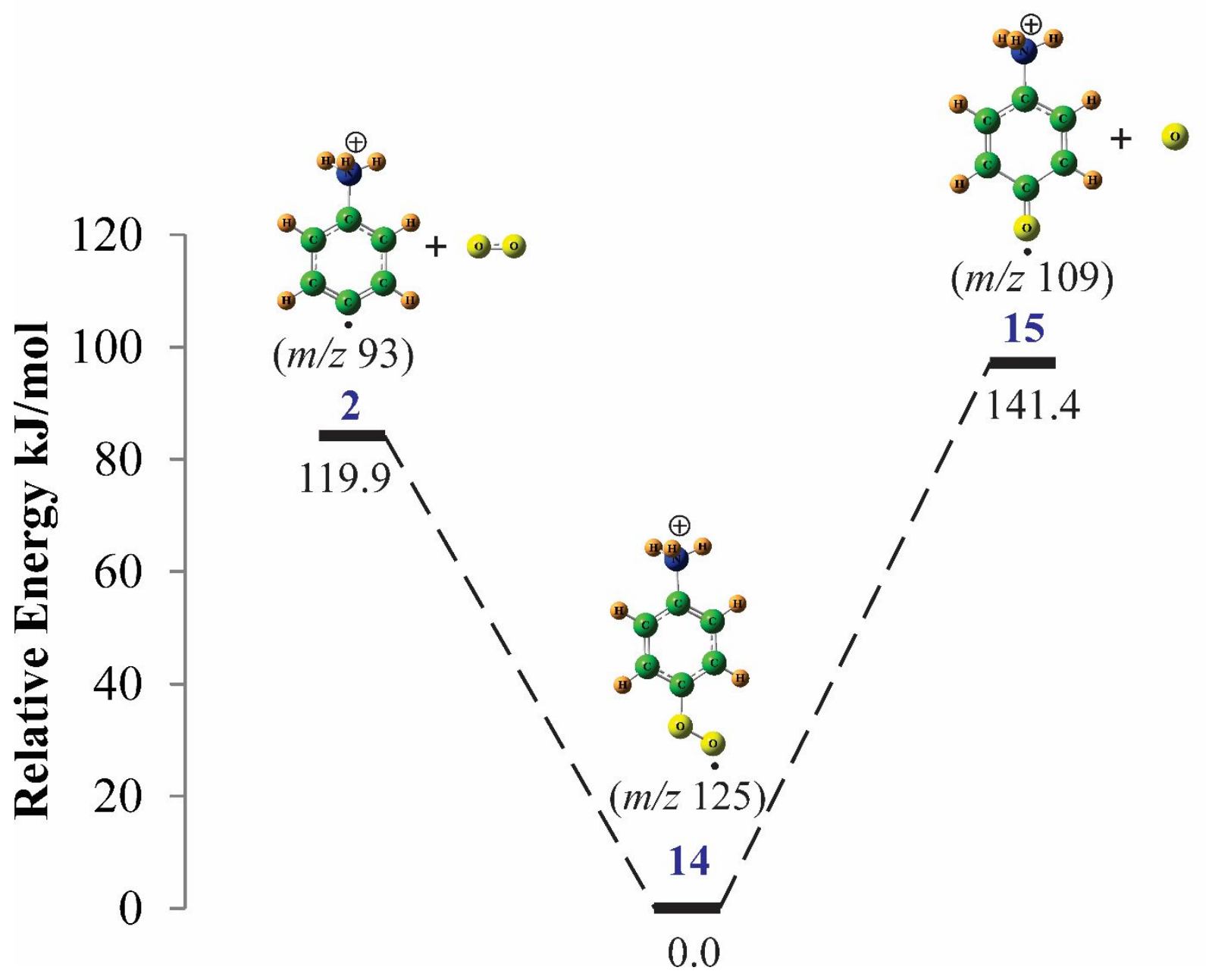

Figure S5. Combined relative electronic and zero point energies [in $\mathrm{kJ} / \mathrm{mol}$ computed for $0 \mathrm{~K}$ by the density functional theory method B3LYP using a 6-311+ $+\mathrm{G}(2 \mathrm{~d}, 2 \mathrm{p})$ basis set] and molecular structures of energy-optimized ions associated with the formation of $\mathrm{m} / z 125$ and 109 ions resulting from the $\mathrm{O}_{2}$ addition to para-dehydroanilinium-radical anion (2). 

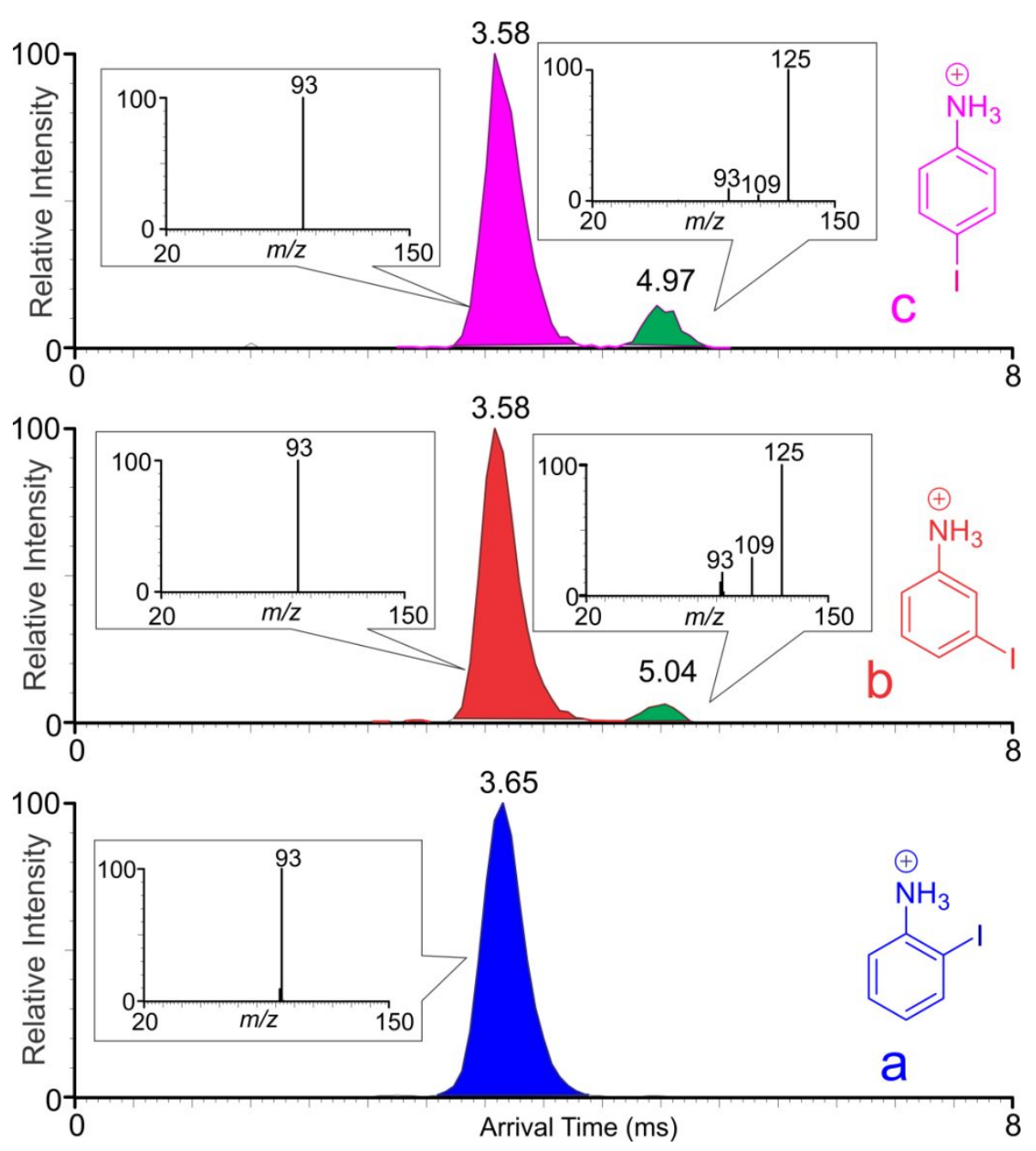

Figure S6. Arrival time distributions (ATDs) recorded from the in-source generated $\mathrm{m} / \mathrm{z} 93$ ion from $o$ (a), $m$ - (b), or $p$-iodoaniline (c), which were mass selected and subjected to ion mobility separation. Ions were generated under ESI conditions (capillary voltage $2.85 \mathrm{kV}$ and cone voltage of $65 \mathrm{~V}$ ) by infusing a 100-ppm solution of each iodoanilines in 50:50 acetonitrile:water. The source and desolvation temperatures were $80^{\circ} \mathrm{C}$ and $100{ }^{\circ} \mathrm{C}$, respectively. The cone gas and deslovation gas flows were $38 \mathrm{~L} / \mathrm{h}$, and $138 \mathrm{~L} / \mathrm{h}$, respectively. The trap collision energy was 4 $\mathrm{eV}$ and transfer collision energy was $2 \mathrm{eV}$. IM separation was carried out a wave velocity of $1500 \mathrm{~m} / \mathrm{s}$, wave height $40.0 \mathrm{~V}$ using nitrogen as IMS gas at a flow of $140 \mathrm{~mL} / \mathrm{min}$. Insets show spectra that represent ions delivered to the ToF analyzer at specific arrival times. 
<smiles>[NH3+]c1ccccc1</smiles>

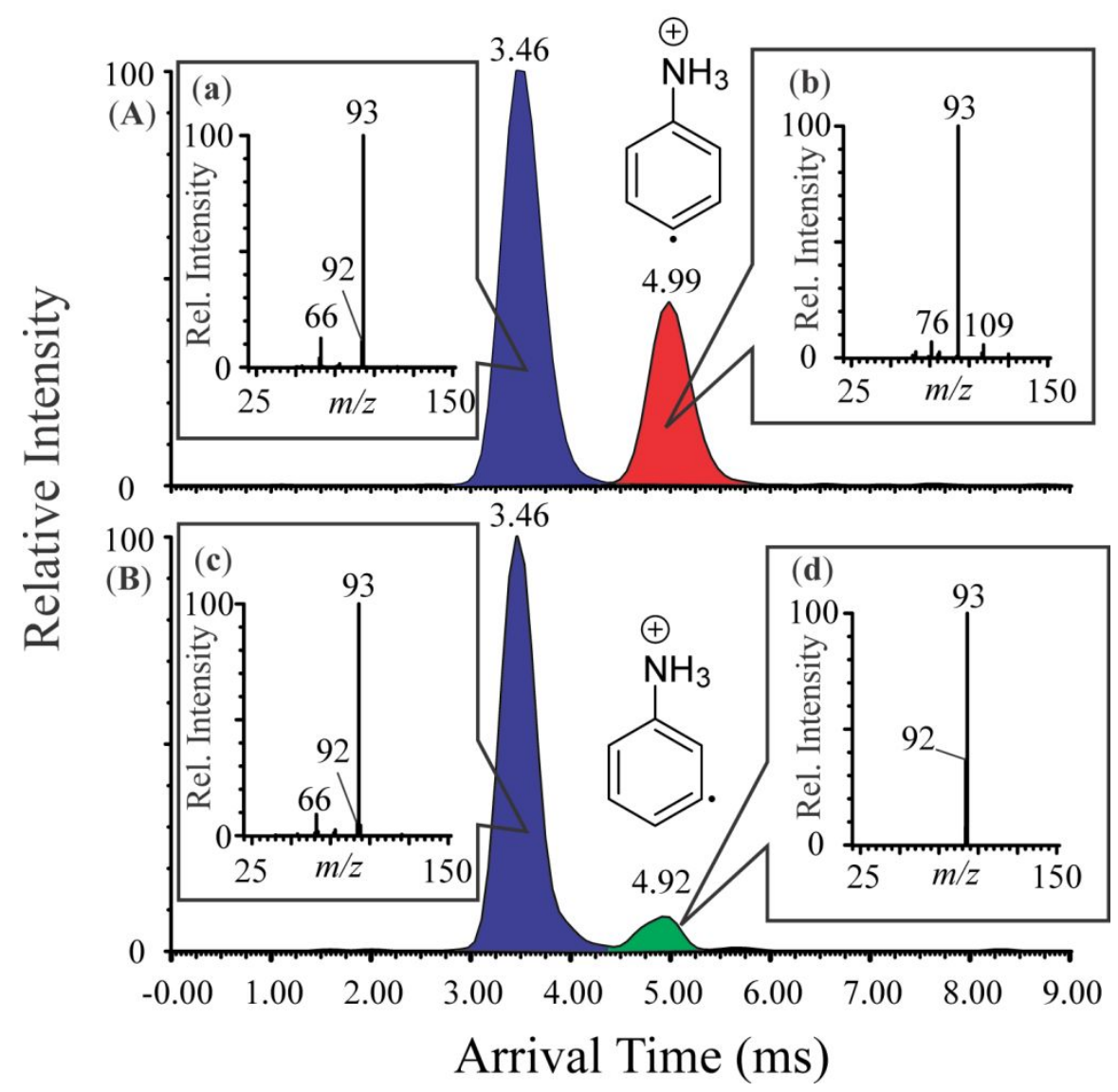

Figure S7. Arrival-time distributions (ATDs) recorded from the mass-selected $\mathrm{m} / \mathrm{z} 93$ ion of $p$-iodoaniline (A), and that of $m$-iodoaniline (B) recorded at a Transfer-collision energy setting of $\mathbf{2 0} \mathbf{e V}$. Insets show average spectra that represent ions delivered to the ToF analyzer at specific arrival times. Ions were generated by electrospraying 100-ppm solutions in 50:50 acetonitrile:water at a flow rate of $20 \mu \mathrm{L} / \mathrm{min}$. Other experimental conditions were as follows: sampling-cone voltage $65 \mathrm{~V}$; capillary voltage $2.85 \mathrm{kV}$; source and desolvation heater temperatures of 80 and $100{ }^{\circ} \mathrm{C}$, respectively; cone and desolvation gas flow rates were 38 and $138 \mathrm{~L} / \mathrm{h}$, respectively; Trap-collision energy $4.0 \mathrm{eV}$. IM separations were carried out at a wave velocity of $1500 \mathrm{~m} / \mathrm{s}$, a wave height $40.0 \mathrm{~V}$, and mobility gas $\left(\mathrm{N}_{2}\right)$ flow rate $140 \mathrm{~mL} / \mathrm{min}$. 


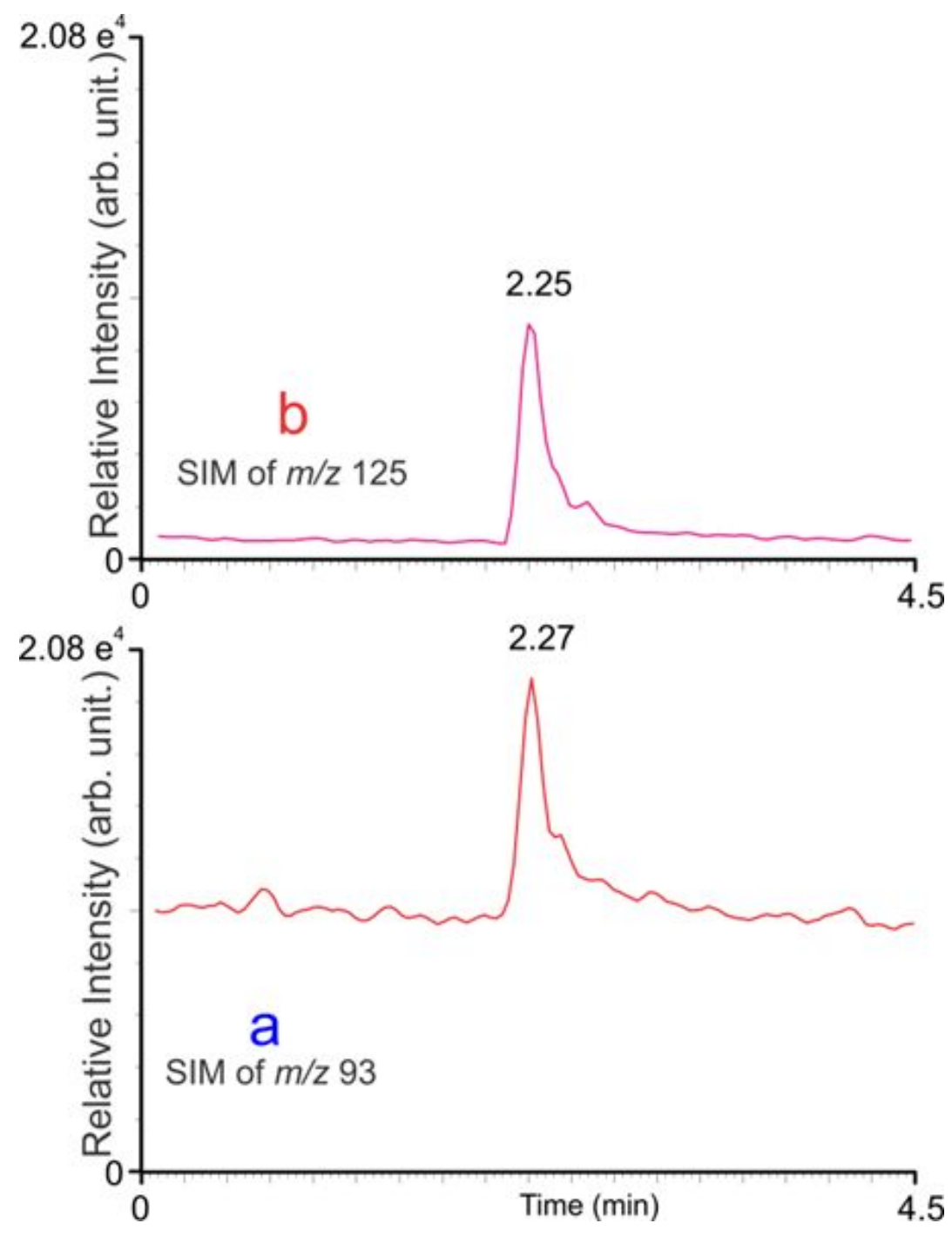

Figure S8. Chronogram recorded by monitoring the intensisties of $m / z 93$ (a), and 125 (b) ions on two detection channels. A 100-ppm solution of aniline was nebulized under ESI conditions by infusing via the main spray probe continuously. At $2.0 \mathrm{~min}$, a $10-\mu \mathrm{L}$ aliquot of a $p$-iodoaniline solution (100 ppm in 50:50 acetonitrile:water) was introduced via the lock-spray probe. Other instrumental parameters were: The sampling cone voltage $70 \mathrm{~V}$; capillary voltage $3.85 \mathrm{kV}$; source and desolvation temperature $80{ }^{\circ} \mathrm{C}$ and $100{ }^{\circ} \mathrm{C}$, respectively; cone and deslovation gas flow $34 \mathrm{~L} / \mathrm{h}$, and $138 \mathrm{~L} / \mathrm{h}$, respectively; trap and transfer collision energy 4 and $2 \mathrm{eV}$, respectively; IM wave velocity of $1500 \mathrm{~m} / \mathrm{s}$; IM wave height $40.0 \mathrm{~V}$; IMS $\left(\mathrm{N}_{2}\right)$ gas flow 140 $\mathrm{mL} / \mathrm{min}$. 
Table S1. Accurate mass data of some ions generated from the interaction of molecular oxygen with dehydroanilinium ions.

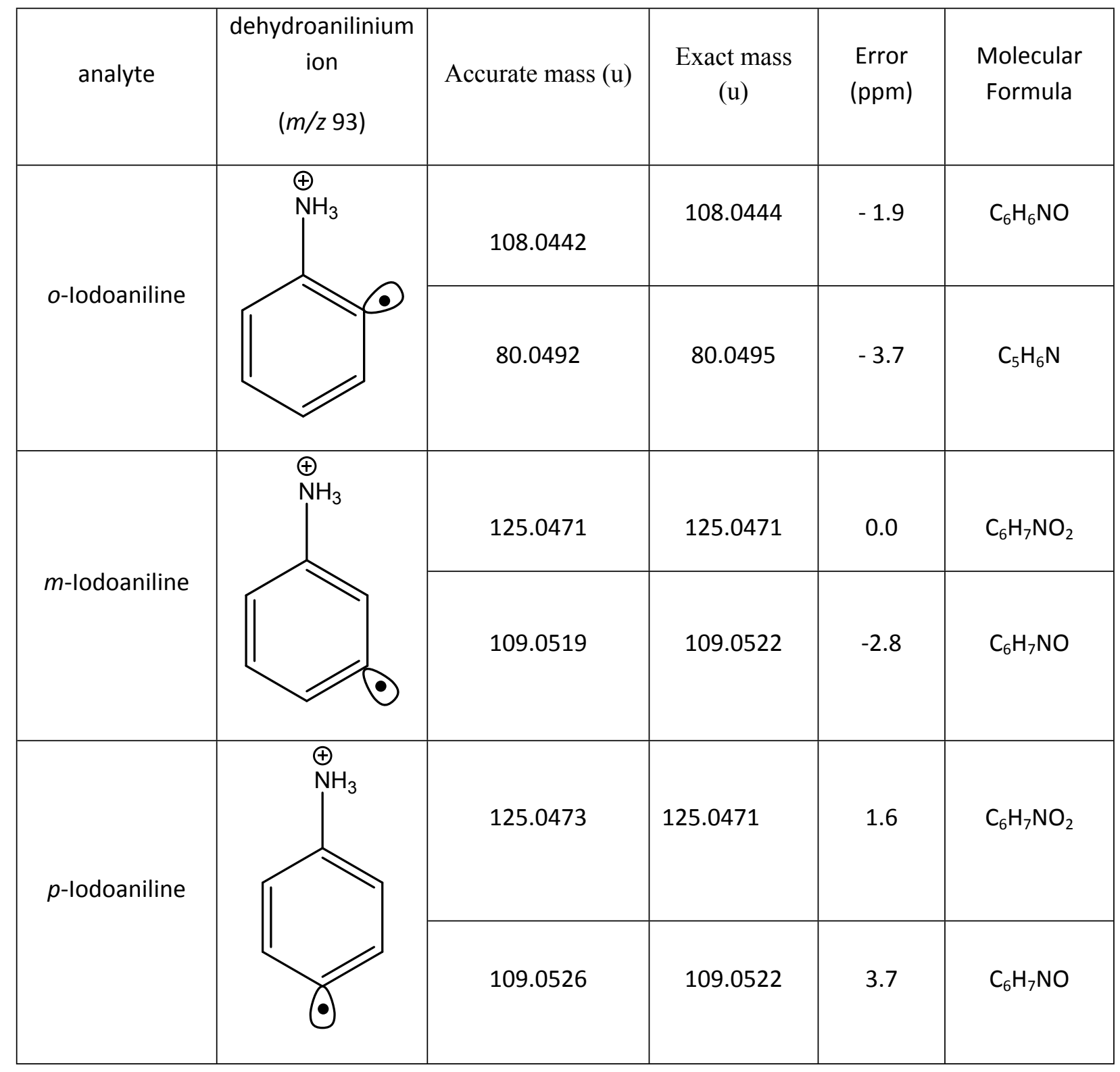


Table S2. Atom coordinates and absolute energies of energy-optimized $\mathrm{O}_{2}$ molecule.

\section{Oxygen molecule triplet}
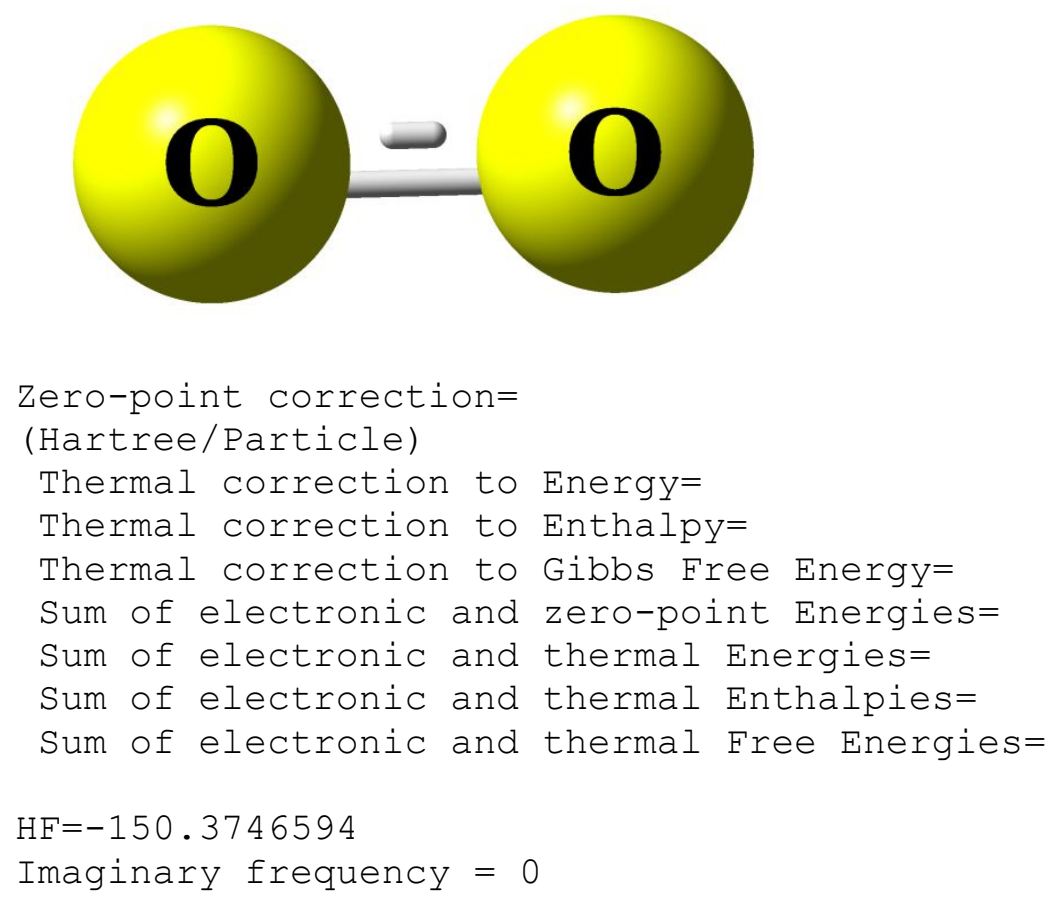
Table S4. Atom coordinates and absolute energies of energy-optimized ortho-dehydroanilinium radicalcations $(\mathrm{m} / \mathrm{z} 93$ ion)

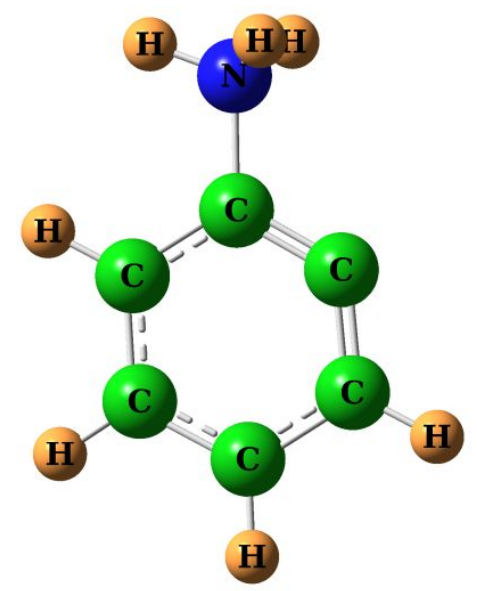

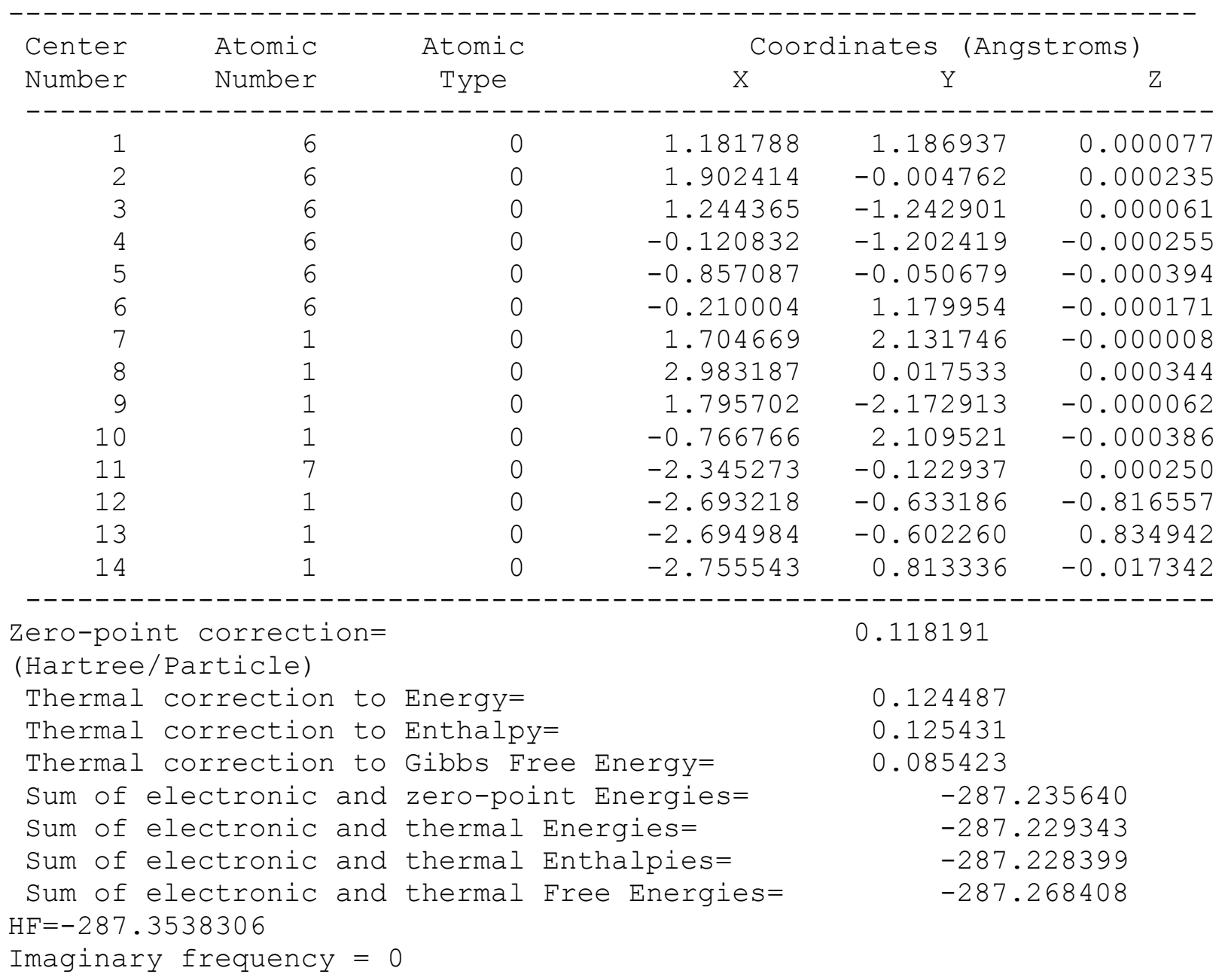


Table S5. Atom coordinates and absolute energies of energy-optimized $o$-peroxylbenzenaminium radicalcation $(m / z 125)$

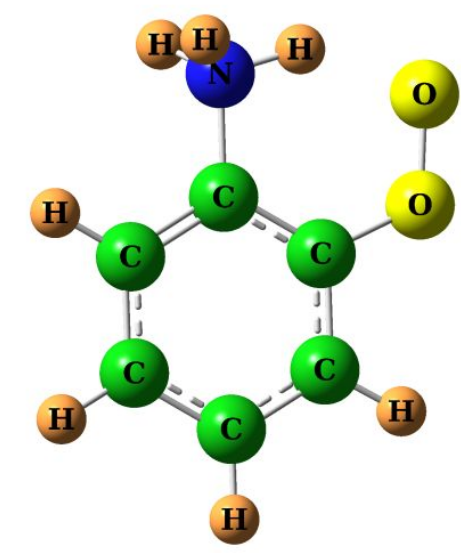

\begin{tabular}{|c|c|c|c|c|c|}
\hline \multirow{2}{*}{$\begin{array}{l}\text { Center } \\
\text { Number }\end{array}$} & \multirow{2}{*}{$\begin{array}{l}\text { Atomic } \\
\text { Number }\end{array}$} & \multirow{2}{*}{$\begin{array}{c}\text { Atomic } \\
\text { Type }\end{array}$} & \multicolumn{3}{|c|}{ Coordinates (Angstroms) } \\
\hline & & & $\mathrm{X}$ & Y & Z \\
\hline 1 & 6 & 0 & 2.126475 & -0.925320 & -0.000019 \\
\hline 2 & 6 & 0 & 0.844611 & -1.453225 & 0.000215 \\
\hline 3 & 6 & 0 & -0.251251 & -0.594237 & 0.000176 \\
\hline 4 & 6 & 0 & -0.058682 & 0.790015 & 0.000078 \\
\hline 5 & 6 & 0 & 1.222082 & 1.312346 & -0.000203 \\
\hline 6 & 6 & 0 & 2.318477 & 0.453662 & -0.000259 \\
\hline 7 & 1 & 0 & 2.976372 & -1.591743 & -0.0000 \\
\hline 8 & 1 & 0 & 0.666492 & -2.519121 & 0.0003 \\
\hline 9 & 1 & 0 & 1.370102 & 2.384494 & -0.000315 \\
\hline 10 & 1 & 0 & 3.316531 & 0.865855 & -0.000432 \\
\hline 11 & 1 & 0 & -1.250951 & 2.292781 & 0.829717 \\
\hline 12 & 1 & 0 & -1.249098 & 2.295601 & -0.827001 \\
\hline 13 & 8 & 0 & -1.471953 & -1.253774 & 0.000355 \\
\hline 14 & 8 & 0 & -2.575139 & -0.516525 & -0.000770 \\
\hline 15 & 1 & 0 & -2.068911 & 1.059790 & -0.0012 \\
\hline 16 & 7 & 0 & -1.227724 & 1.696471 & 0.0003 \\
\hline
\end{tabular}

Zero-point correction=

0.126528

(Hartree/Particle)

Thermal correction to Energy=

0.134089

Thermal correction to Enthalpy=

Thermal correction to Gibbs Free Energy=

Sum of electronic and zero-point Energies=

0.135033

Sum of electronic and thermal Energies=

0.093819

$-437.673782$

$-437.666220$

$-437.665276$

Sum of electronic and thermal Enthalpies=

$-437.706491$

$\mathrm{HF}=-437.8003092$

Imaginary frequency $=0$ 
Table S6. Atom coordinates and absolute energies of the transition state of $\mathrm{OH}$ radical loss from $o$ peroxylbenzenaminium radical-cation.

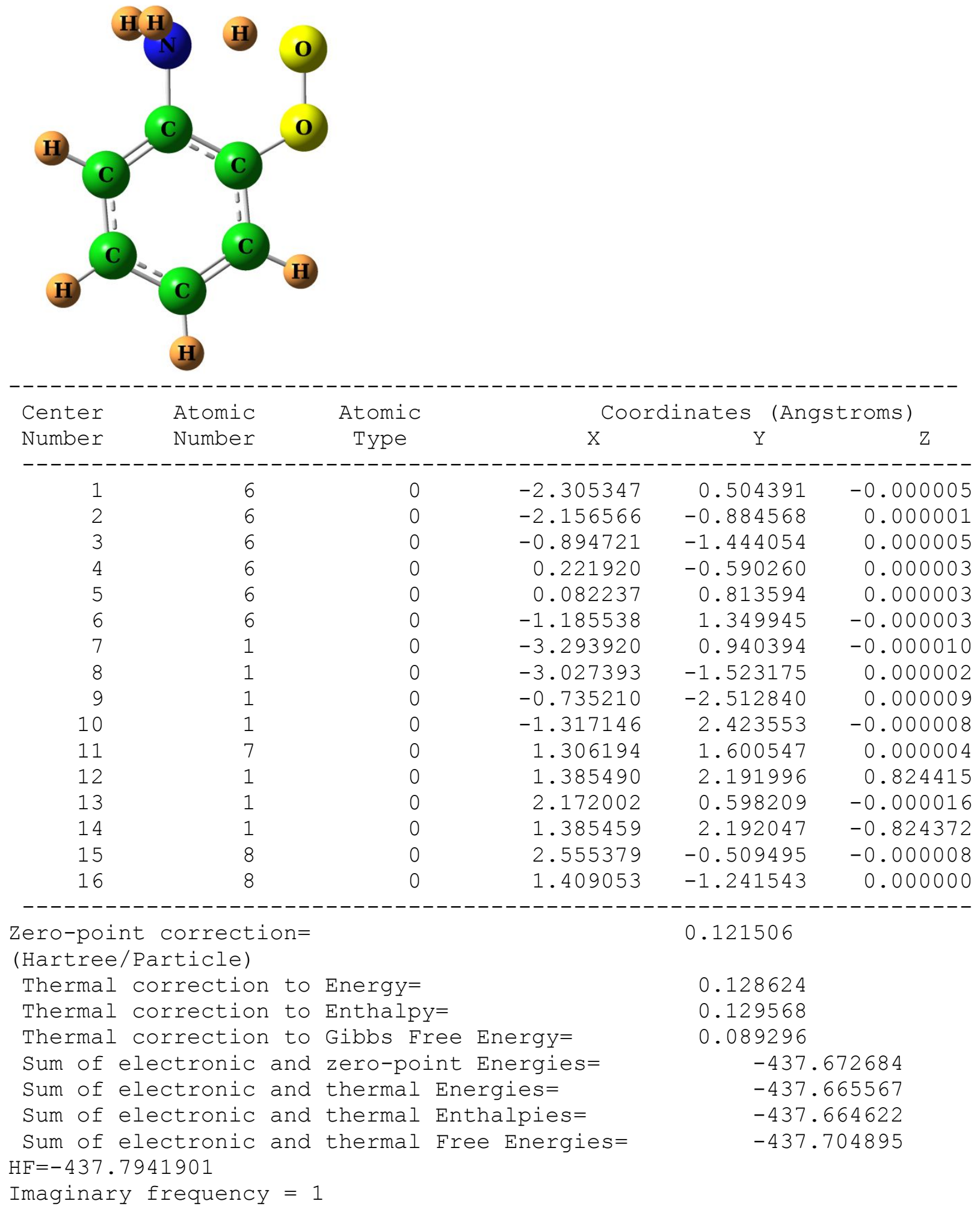


Table S7. Atom coordinates and absolute energies of the complex of $\mathrm{OH}$ radical and protonated orthoquinonimide.

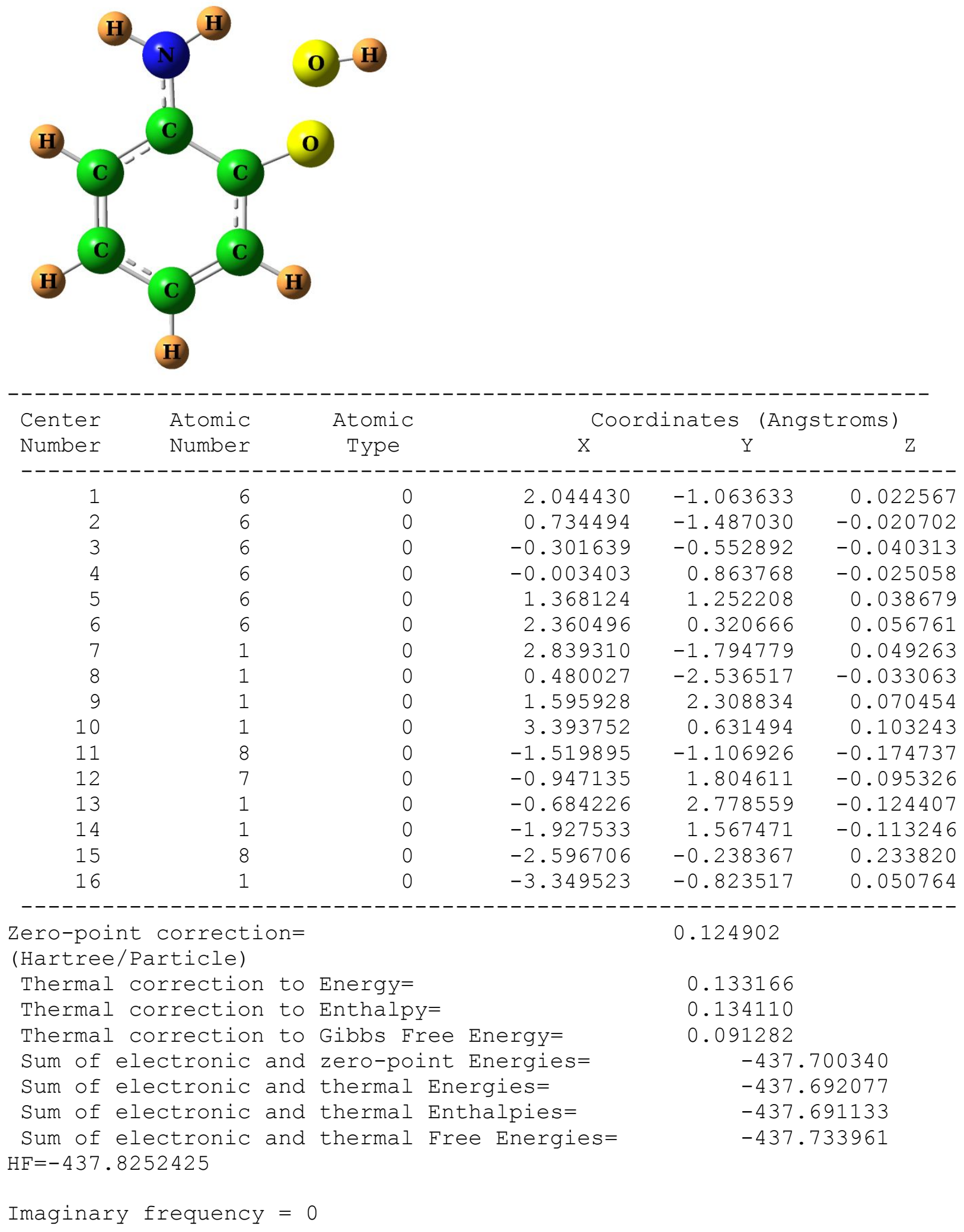


Table S8. Atom coordinates and absolute energies of protonated ortho-quinonimide $(\mathrm{m} / \mathrm{z} 108)$.

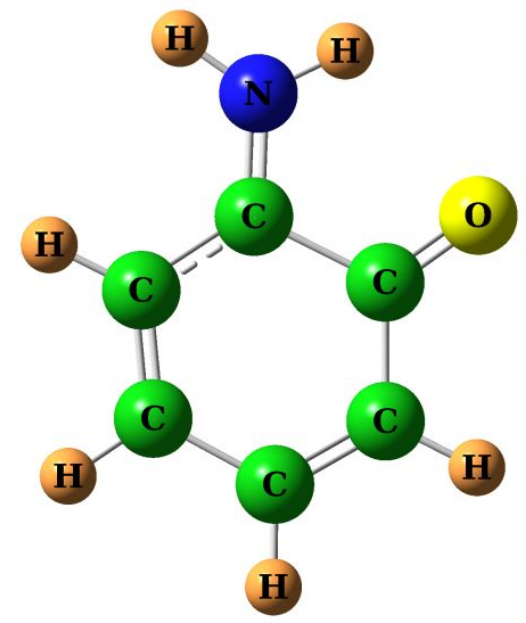

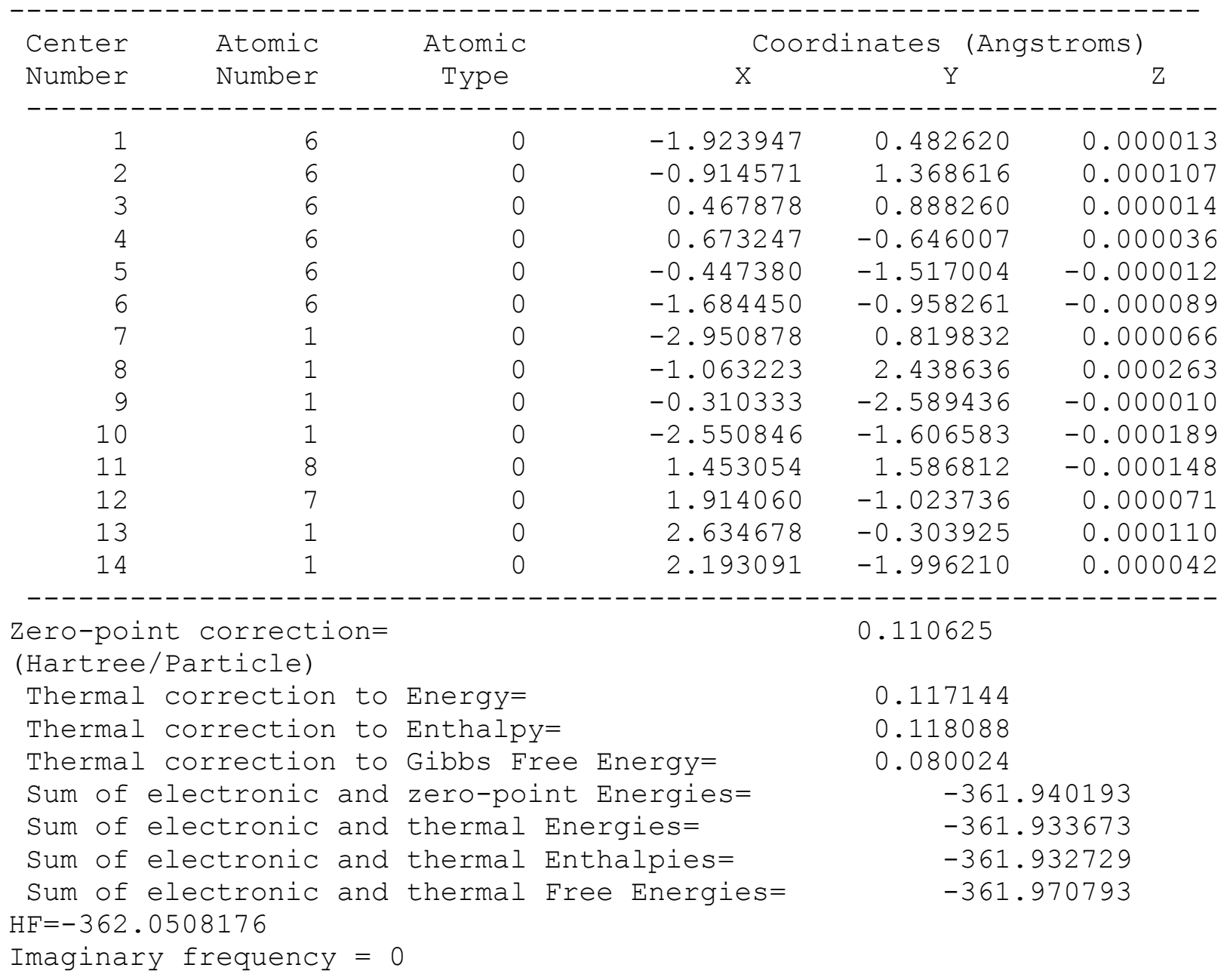


Table S9. Atom coordinates and absolute energies of protonated cyclopenta-2,4-dien-1-imine $(\mathrm{m} / \mathrm{z} 80)$.

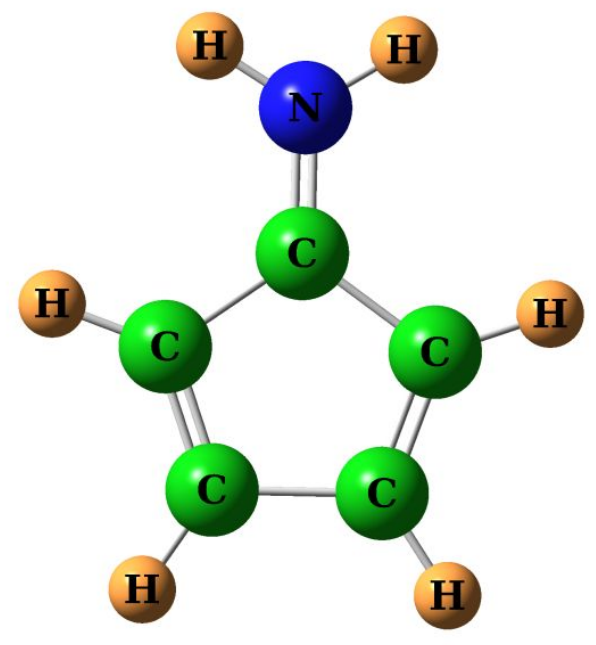

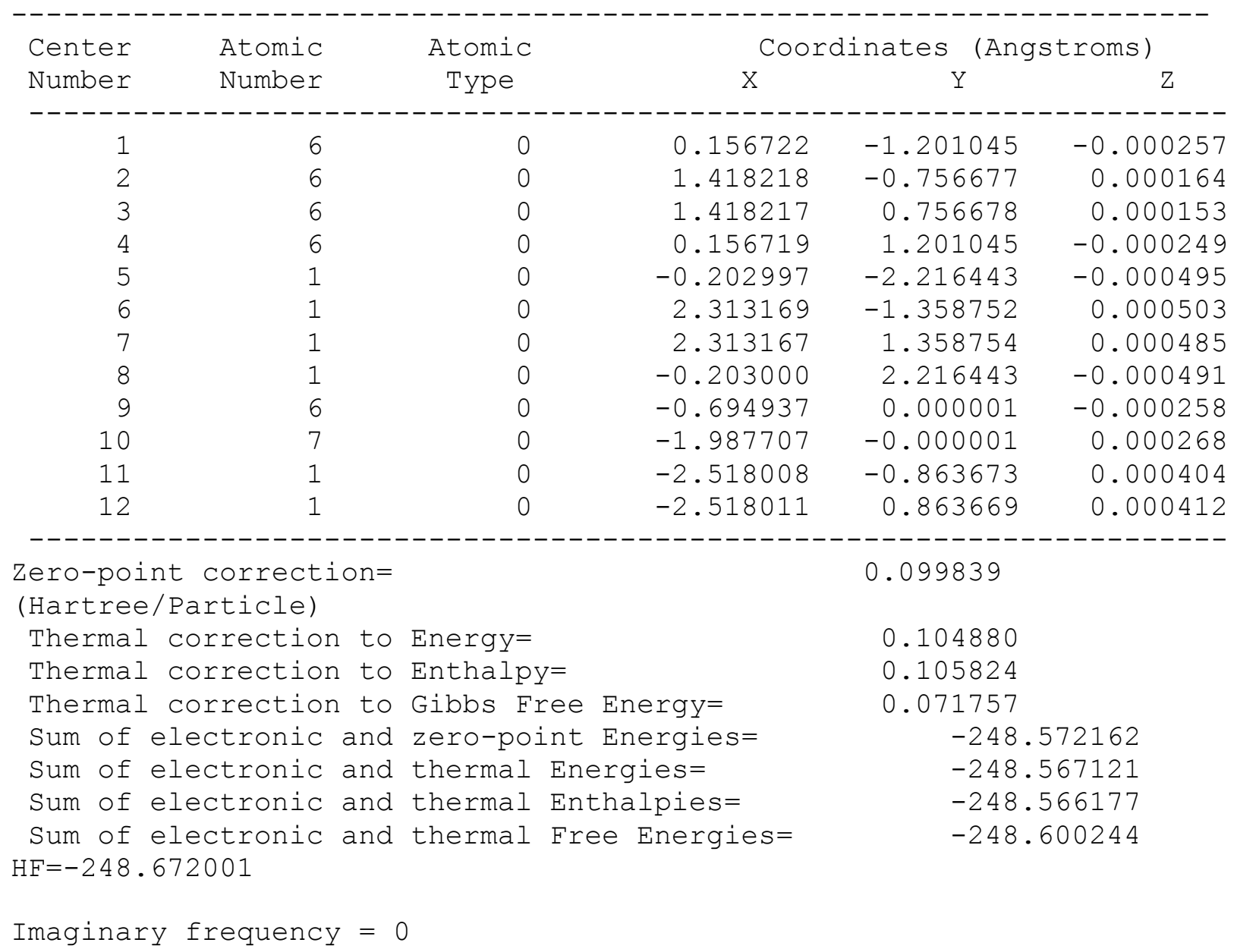


Table S10. Atom coordinates and absolute energies of energy-optimized meta-dehydroanilinium radicalcations $(\mathrm{m} / \mathrm{z} 93$ ion)

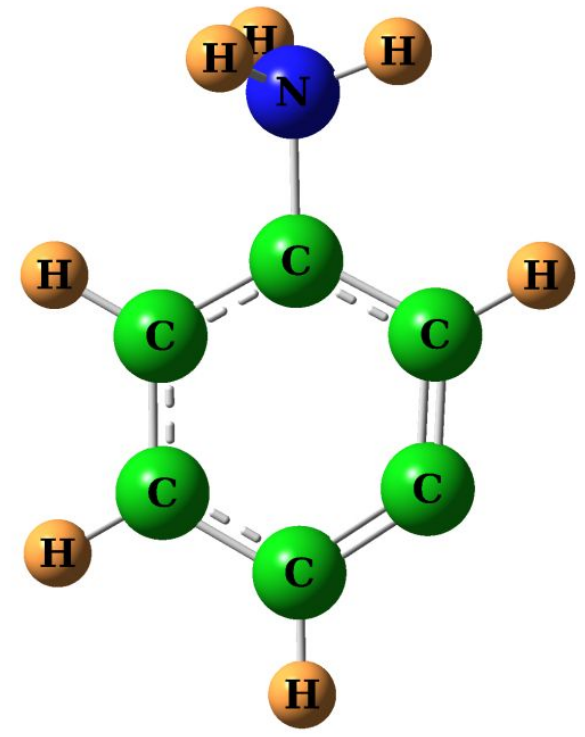

\begin{tabular}{|c|c|c|c|c|c|c|}
\hline \multirow{2}{*}{\multicolumn{2}{|c|}{$\begin{array}{l}\text { Center } \\
\text { Number }\end{array}$}} & \multirow{2}{*}{$\begin{array}{l}\text { Atomic } \\
\text { Number }\end{array}$} & \multirow{2}{*}{$\begin{array}{l}\text { Atomic } \\
\text { Type }\end{array}$} & \multicolumn{3}{|c|}{ Coordinates (Angstroms) } \\
\hline & & & & $\mathrm{X}$ & $\mathrm{Y}$ & Z \\
\hline & 1 & 6 & 0 & $-1 \quad 966387$ & 0178336 & 0.001553 \\
\hline & $\begin{array}{l}1 \\
2\end{array}$ & $\begin{array}{l}6 \\
6\end{array}$ & 0 & -1.147497 & $\begin{array}{l}.118350 \\
1.275877\end{array}$ & 0.000420 \\
\hline & 3 & 6 & 0 & 0.224087 & 1.267974 & -0.001477 \\
\hline & 4 & 6 & 0 & 0.793953 & -0.000297 & -0.002224 \\
\hline & 5 & 6 & 0 & 0.047357 & -1.168420 & -0.001462 \\
\hline & 6 & 6 & 0 & -1.341598 & -1.074436 & 0.000347 \\
\hline & 7 & 1 & 0 & -3.044152 & 0.262214 & 0.002394 \\
\hline & 8 & 1 & 0 & 0.811160 & 2.178433 & -0.002608 \\
\hline & 9 & 1 & 0 & 0.524274 & -2.139620 & -0.002648 \\
\hline & 10 & 1 & 0 & -1.938309 & -1.975652 & -0.000085 \\
\hline & 11 & 7 & 0 & 2.287402 & -0.112990 & 0.002041 \\
\hline & 12 & 1 & 0 & 2.632664 & -0.534608 & 0.868597 \\
\hline & 13 & 1 & 0 & 2.623338 & -0.683197 & -0.778460 \\
\hline & 14 & 1 & 0 & 2.719722 & 0.809144 & -0.084420 \\
\hline $\begin{array}{l}\text { Zero-p } \\
\text { (Hartr }\end{array}$ & $\begin{array}{l}\text { poir } \\
\text { ree/ }\end{array}$ & $\begin{array}{l}\text { nt correction= } \\
\text { /Particle) }\end{array}$ & & & 0.117951 & \\
\hline Thern & mal & correction to & Energy= & & 0.123311 & \\
\hline Thern & mal & correction to & Enthalpy= & & 0.124255 & \\
\hline Thern & mal & correction to & Gibbs Fre & ee Energy= & 0.088356 & \\
\hline Sum $c$ & of $\in$ & electronic and & zero-poin & it Energies= & -287 & 34510 \\
\hline Sum $c$ & of $\epsilon$ & electronic and & thermal E & Energies= & -287 & 29150 \\
\hline Sum c & of $\epsilon$ & electronic and & thermal $\mathrm{E}$ & inthalpies $=$ & -287 & 28206 \\
\hline Sum $c$ & of $\epsilon$ & electronic and & thermal $\mathrm{F}$ & ree Energies= & -287 & 64105 \\
\hline
\end{tabular}


Table S11. Atom coordinates and absolute energies of energy-optimized $m$-peroxylbenzenaminium radical-cation $(\mathrm{m} / \mathrm{z} 125)$

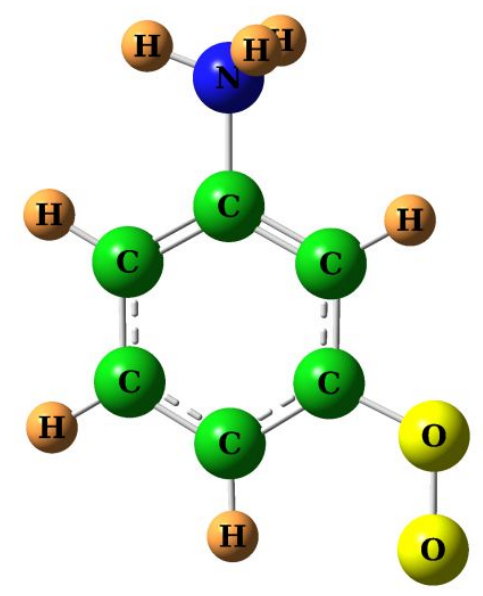

\begin{tabular}{|c|c|c|c|c|c|}
\hline \multirow{2}{*}{$\begin{array}{l}\text { Center } \\
\text { Number }\end{array}$} & \multirow{2}{*}{$\begin{array}{l}\text { Atomic } \\
\text { Number }\end{array}$} & \multirow{2}{*}{$\begin{array}{l}\text { Atomic } \\
\text { Type }\end{array}$} & \multicolumn{3}{|c|}{ Coordinates (Angstroms) } \\
\hline & & & $\mathrm{X}$ & $\mathrm{Y}$ & Z \\
\hline 1 & 6 & 0 & 0.873996 & 1.177844 & 0.001286 \\
\hline 2 & 6 & 0 & 0.874371 & -0.211699 & 0.000213 \\
\hline 3 & 6 & 0 & -0.301161 & -0.952803 & -0.001349 \\
\hline 4 & 6 & 0 & -1.487048 & -0.241841 & -0.002127 \\
\hline 5 & 6 & 0 & -1.545714 & 1.140319 & -0.001308 \\
\hline 6 & 6 & 0 & -0.342617 & 1.844940 & 0.000366 \\
\hline 7 & 1 & 0 & 1.812023 & 1.710076 & 0.001853 \\
\hline 8 & 1 & 0 & -0.255467 & -2.033658 & -0.002170 \\
\hline 9 & 1 & 0 & -2.489431 & 1.669460 & -0.002334 \\
\hline 10 & 1 & 0 & -0.360417 & 2.924753 & 0.000230 \\
\hline 11 & 7 & 0 & -2.766812 & -1.012576 & 0.001928 \\
\hline 12 & 1 & 0 & -2.883587 & -1.549996 & 0.865648 \\
\hline 13 & 1 & 0 & -3.566797 & -0.381172 & -0.077328 \\
\hline 14 & 1 & 0 & -2.815034 & -1.668359 & -0.782550 \\
\hline 15 & 8 & 0 & 2.031628 & -0.981268 & -0.000265 \\
\hline 16 & 8 & 0 & 3.155301 & -0.284185 & 0.000349 \\
\hline $\begin{array}{l}\text { Zero-po: } \\
\text { (Hartree }\end{array}$ & $\begin{array}{l}\text { nt correction= } \\
\text { /Particle) }\end{array}$ & & & 0.126447 & \\
\hline Therma & correction to & Energy= & & 0.134708 & \\
\hline Therma] & correction to & Enthalpy $=$ & & 0.135652 & \\
\hline Therma & correction to & Gibbs Fre & ee Energy= & 0.090851 & \\
\hline Sum of & electronic and & zero-poin & nt Energies= & -437 & 66521 \\
\hline Sum of & electronic and & thermal $\mathrm{E}$ & Energies= & -437 & 58260 \\
\hline Sum of & electronic and & thermal $\mathrm{E}$ & Enthalpies= & -437 & 57316 \\
\hline $\begin{array}{r}\text { Sum of } \\
\mathrm{HF}=-437\end{array}$ & $\begin{array}{l}\text { electronic and } \\
7929681\end{array}$ & thermal $\mathrm{F}$ & Free Energies= & -437 & 02117 \\
\hline
\end{tabular}


Table S12. Atom coordinates and absolute energies of protonated meta-quinonimide $(\mathrm{m} / \mathrm{z} 109)$.

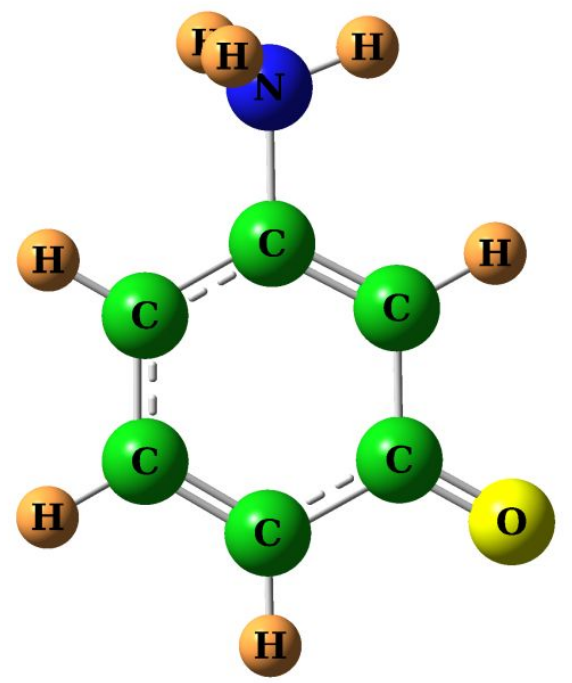

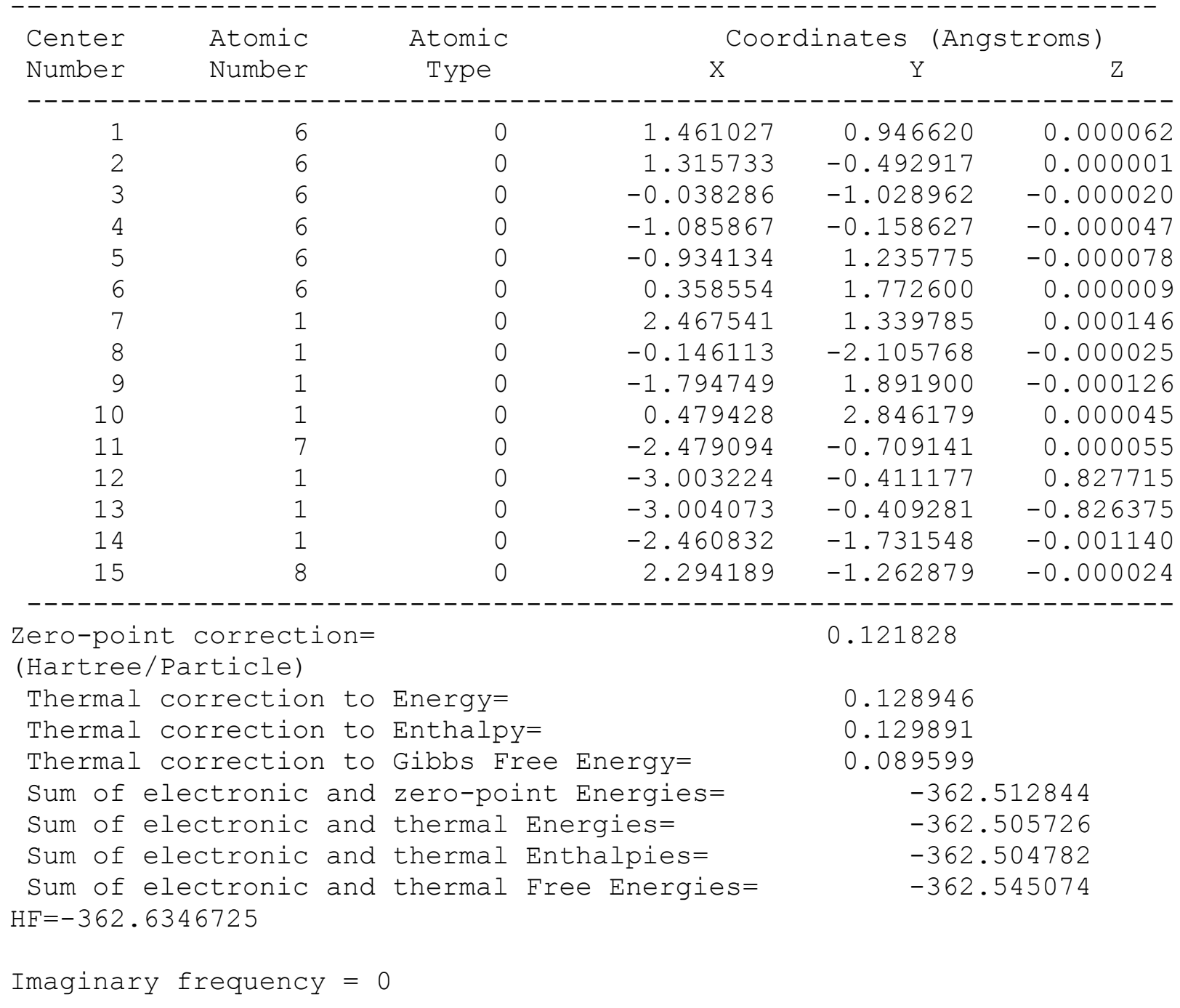


Table S13. Atom coordinates and absolute energies of energy-optimized $p$-dehydroanilinium radicalcations $(\mathrm{m} / \mathrm{z} 93$ ion)

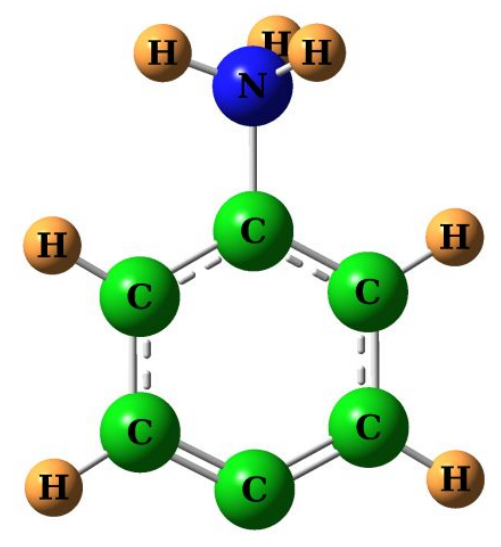

\begin{tabular}{|c|c|c|c|c|c|}
\hline \multirow{2}{*}{$\begin{array}{l}\text { Center } \\
\text { Number }\end{array}$} & \multirow{2}{*}{$\begin{array}{l}\text { Atomic } \\
\text { Number }\end{array}$} & \multirow{2}{*}{$\begin{array}{c}\text { Atomic } \\
\text { Type }\end{array}$} & \multicolumn{3}{|c|}{ Coordinates (Angstroms) } \\
\hline & & & $\mathrm{x}$ & Y & Z \\
\hline 1 & 6 & 0 & -1.295420 & 1.225394 & 0.000160 \\
\hline 2 & 6 & 0 & -1.909646 & 0.000646 & 0.000548 \\
\hline 3 & 6 & 0 & -1.293642 & -1.225574 & 0.000187 \\
\hline 4 & 6 & 0 & 0.102824 & -1.225270 & -0.000474 \\
\hline 5 & 6 & 0 & 0.755295 & -0.000309 & -0.000759 \\
\hline 6 & 6 & 0 & 0.102862 & 1.222596 & -0.000433 \\
\hline 7 & 1 & 0 & -1.846514 & 2.155192 & 0.000033 \\
\hline 8 & 1 & 0 & -1.846253 & -2.154494 & 0.000129 \\
\hline 9 & 1 & 0 & 0.649626 & -2.160028 & -0.000826 \\
\hline 10 & 1 & 0 & 0.649641 & 2.157763 & -0.000794 \\
\hline 11 & 7 & 0 & 2.250156 & -0.000124 & 0.000620 \\
\hline 12 & 1 & 0 & 2.629225 & -0.446967 & 0.839828 \\
\hline 13 & 1 & 0 & 2.629865 & -0.491800 & -0.812693 \\
\hline 14 & 1 & 0 & 2.609668 & 0.956301 & -0.025393 \\
\hline
\end{tabular}

Zero-point correction=

(Hartree/Particle)

Thermal correction to Energy=

Thermal correction to Enthalpy=

Thermal correction to Gibbs Free Energy=

Sum of electronic and zero-point Energies=

Sum of electronic and thermal Energies=

Sum of electronic and thermal Enthalpies=

Sum of electronic and thermal Free Energies= $\mathrm{HF}=-287.3526315$

Imaginary frequency $=0$
0.118107
0.124297
0.125242
0.086988
$-287.234524$
$-287.228334$
$-287.227390$
$-287.265644$ 
Table S14. Atom coordinates and absolute energies of energy-optimized $p$-peroxylbenzenaminium radical-cation $(m / z 125)$

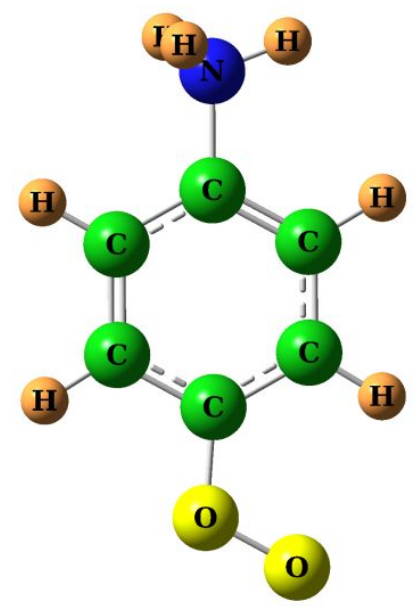

\begin{tabular}{|c|c|c|c|c|c|}
\hline \multirow{2}{*}{$\begin{array}{l}\text { Center } \\
\text { Number }\end{array}$} & \multirow{2}{*}{$\begin{array}{l}\text { Atomic } \\
\text { Number }\end{array}$} & \multirow{2}{*}{$\begin{array}{c}\text { Atomic } \\
\text { Type }\end{array}$} & \multicolumn{3}{|c|}{ Coordinates (Angstroms) } \\
\hline & & & $\mathrm{X}$ & Y & Z \\
\hline 1 & 6 & 0 & 0.522492 & -1.052331 & -0.000250 \\
\hline 2 & 6 & 0 & 1.046146 & 0.233409 & 0.000132 \\
\hline 3 & 6 & 0 & 0.241580 & 1.369012 & -0.000029 \\
\hline 4 & 6 & 0 & -1.135527 & 1.216250 & -0.000468 \\
\hline 5 & 6 & 0 & -1.654158 & -0.070514 & -0.000732 \\
\hline 6 & 6 & 0 & -0.857450 & -1.203514 & -0.000580 \\
\hline 7 & 1 & 0 & 1.183000 & -1.904452 & -0.000463 \\
\hline 8 & 1 & 0 & 0.695466 & 2.349096 & -0.000002 \\
\hline 9 & 1 & 0 & -1.775839 & 2.088368 & -0.000582 \\
\hline 10 & 1 & 0 & -1.286250 & -2.197400 & -0.000860 \\
\hline 11 & 7 & 0 & -3.137631 & -0.239863 & 0.000900 \\
\hline 12 & 1 & 0 & -3.565457 & 0.159245 & 0.841100 \\
\hline 13 & 1 & 0 & -3.571618 & 0.207194 & -0.811369 \\
\hline 14 & 8 & 0 & 2.410984 & 0.492568 & 0.000096 \\
\hline 15 & 8 & 0 & 3.175756 & -0.585862 & 0.000473 \\
\hline 16 & 1 & 0 & -3.388307 & -1.230531 & -0.027110 \\
\hline
\end{tabular}

Zero-point correction=

(Hartree/Particle)

Thermal correction to Energy=

Thermal correction to Enthalpy=

Thermal correction to Gibbs Free Energy=

Sum of electronic and zero-point Energies=

Sum of electronic and thermal Energies=

Sum of electronic and thermal Enthalpies=

Sum of electronic and thermal Free Energies=

$\mathrm{HF}=-437.7939728$

Imaginary frequency $=0$
0.126534

$$
\begin{array}{r}
0.134738 \\
0.135682 \\
0.091894 \\
-437.667439 \\
-437.659234 \\
-437.658290 \\
-437.702079
\end{array}
$$


Table S15. Atom coordinates and absolute energies of protonated para-quinonimide $(\mathrm{m} / \mathrm{z} 109)$.

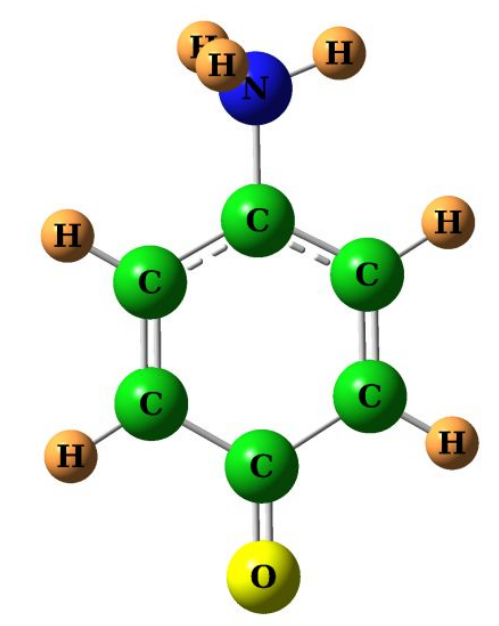

\begin{tabular}{|c|c|c|c|c|c|}
\hline \multirow{2}{*}{$\begin{array}{l}\text { Center } \\
\text { Number }\end{array}$} & \multirow{2}{*}{$\begin{array}{l}\text { Atomic } \\
\text { Number }\end{array}$} & \multirow{2}{*}{$\begin{array}{c}\text { Atomic } \\
\text { Type }\end{array}$} & \multicolumn{3}{|c|}{ Coordinates (Angstroms) } \\
\hline & & & $\mathrm{X}$ & Y & Z \\
\hline 1 & 6 & 0 & -0.816788 & 1.241575 & -0.000322 \\
\hline 2 & 6 & 0 & -1.563637 & -0.000140 & 0.000269 \\
\hline 3 & 6 & 0 & -0.814047 & -1.241854 & 0.000111 \\
\hline 4 & 6 & 0 & 0.559450 & -1.233330 & -0.000502 \\
\hline 5 & 6 & 0 & 1.214116 & 0.001905 & -0.001006 \\
\hline 6 & 6 & 0 & 0.559282 & 1.233216 & -0.000836 \\
\hline 7 & 1 & 0 & -1.377964 & 2.164663 & -0.000543 \\
\hline 8 & 1 & 0 & -1.374975 & -2.165145 & 0.000258 \\
\hline 9 & 1 & 0 & 1.116950 & -2.161626 & -0.000616 \\
\hline 10 & 1 & 0 & 1.114847 & 2.162964 & -0.001248 \\
\hline 11 & 7 & 0 & 2.706786 & -0.000698 & 0.000909 \\
\hline 12 & 1 & 0 & 3.083129 & -0.451013 & 0.840919 \\
\hline 13 & 1 & 0 & 3.084479 & -0.498161 & -0.811243 \\
\hline 14 & 8 & 0 & -2.812160 & -0.001077 & 0.000740 \\
\hline 15 & 1 & 0 & 3.073059 & 0.953589 & -0.026093 \\
\hline
\end{tabular}

Zero-point correction=

(Hartree/Particle)

Thermal correction to Energy=

Thermal correction to Enthalpy=

Thermal correction to Gibbs Free Energy=

Sum of electronic and zero-point Energies=

Sum of electronic and thermal Energies=

Sum of electronic and thermal Enthalpies=

Sum of electronic and thermal Free Energies=

$\mathrm{HF}=-362.6321571$

Imaginary frequency $=0$
0.121677

$$
\begin{array}{r}
0.128864 \\
0.129809 \\
0.088953 \\
-362.510480 \\
-362.503293 \\
-362.502348 \\
-362.543204
\end{array}
$$

